
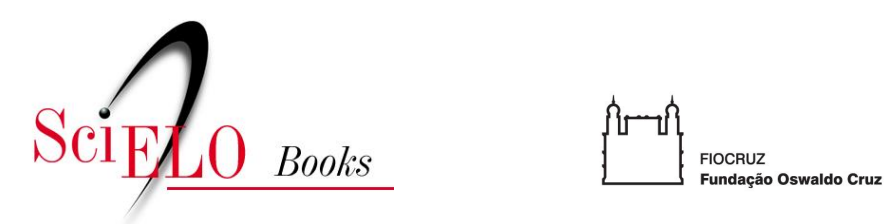

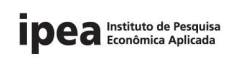

\title{
Cenários macroeconômicos no horizonte 2022/2030
}

\author{
Aloisio Teixeira \\ Salvador Werneck Vianna
}

\section{SciELO Books / SciELO Livros / SciELO Libros}

TEIXEIRA, A., and VIANNA, SW. Cenários macroeconômicos no horizonte 2022/2030. In FUNDAÇÃO OSWALDO CRUZ. A saúde no Brasil em 2030 - prospecção estratégica do sistema de saúde brasileiro: desenvolvimento, Estado e políticas de saúde [online]. Rio de Janeiro: Fiocruz/Ipea/Ministério da Saúde/Secretaria de Assuntos Estratégicos da Presidência da República, 2013. Vol. 1. pp. 19-59. ISBN 978-85-8110-015-9. Available from SciELO Books <http://books.scielo.org>.

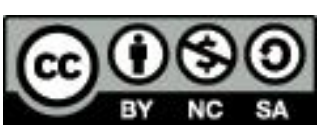

All the contents of this chapter, except where otherwise noted, is licensed under a Creative Commons Attribution-Non Commercial-ShareAlike 3.0 Unported.

Todo o conteúdo deste capítulo, exceto quando houver ressalva, é publicado sob a licença Creative Commons Atribuição Uso Não Comercial - Partilha nos Mesmos Termos 3.0 Não adaptada.

Todo el contenido de este capítulo, excepto donde se indique lo contrario, está bajo licencia de la licencia Creative Commons Reconocimento-NoComercial-CompartirIgual 3.0 Unported. 
Cenários Macroeconômicos no Horizonte 2022/2030 


\title{
CENÁRIOS MACROECONÔMICOS NO HORIZONTE 2022/2030
}

\author{
Aloisio Teixeira \\ Salvador Werneck Vianna
}

"Ó homem, conhece-te a ti mesmo e conhecerás os deuses e o universo" (Inscrição no Oráculo de Delfos, atribuída aos Sete

Sábios da Grécia - 650 a.C.-550 a.C.)

\section{1 | INTRODUÇÃO}

-É possível conhecer o futuro?

As pitonisas do Oráculo de Delfos diriam que sim. E não apenas elas, mas todos os que reclamam para si os poderes da arte divinatória - das cartas de tarot aos búzios; da mitologia escandinava, em que Odin leva a cabeça do deus Mimir para Asqard nela consultar o futuro, ao I Ching, que na dinastia Shang foi usado para a adivinhação. Tudo isso revelando a complexa relação que o homem mantém com seu destino.

- Mais precisamente: é possível prever o cenário em que estará vivendo a economia brasileira em um horizonte de 20 anos?

Embora as duas perguntas se pareçam, há uma sutileza que as distingue. Se a primeira está contida naquilo que podemos considerar como o domínio dos deuses ou da sorte e pode ser vista como a monótona repetição dos ciclos da natureza ou como o resultado de fenômenos que fogem ao controle dos homens, a segunda merece uma reflexão mais rigorosa.

O presente texto não pretende responder a essa pergunta. Na verdade ele integra um trabalho mais amplo, destinado à discussão das condições que o sistema de saúde brasileiro viverá na quarta década do Século XXI, sendo seu objetivo tão somente desenhar cenários macroeconômicos possíveis em um horizonte de 20 anos. Como parte desse trabalho, deverá, portanto, criar uma moldura descritiva do desempenho 
das variáveis macroeconômicas, de modo a permitir a visualização das alternativas que estarão colocadas para o sistema nacional de saúde, em termos de limites e possibilidades, e que condicionarão tanto seu desenvolvimento quanto a elaboração de políticas públicas para o setor.

Para atingir seus objetivos, o trajeto a ser percorrido será o seguinte:

1. Resumo do quadro macroeconômico atual e dos principais pontos de vista presentes no debate sobre a economia brasileira.

2. Discussão sobre conceito e a método presentes em estudos prospectivos; limites ao uso de cenários para previsão do quadro macroeconômico.

3. Levantamento bibliográfico e resenha dos principais trabalhos prospectivos recentes.

4. Definição das variáveis a serem utilizadas na construção dos cenários.

5. Breve descrição dos cenários alternativos no horizonte de 20 anos.

\section{2 | CENÁRIO MACROECONÔMICO ATUAL: BREVE DESCRIÇÃO}

A história econômica brasileira do Século XX reúne diversos exemplos de como a condução da política macroeconômica pode condicionar a trajetória de desenvolvimento, bem como as flutuações do produto, da renda e dos preços. Por isso, uma breve descrição do cenário macroeconômico vigente no país nos dias de hoje tornase necessária: ela constitui o ponto de partida para o desenho dos cenários futuros.

Para dar conta dessa descrição, ainda que de modo extremamente simplificado, a evolução da economia brasileira será dividida em dois períodos: o que vai de 1930 a 1980, de acelerado crescimento; o que transcorre entre 1980 e 2009, de lento crescimento (ou mesmo semiestagnação).

\subsection{Cinquenta Anos de Intenso Crescimento Econômico}

A economia brasileira percorreu no meio século compreendido entre 1930 e 1980, uma trajetória de crescimento econômico singular no conjunto dos países da periferia do capitalismo mundial. Ao fim desse longo período, a renda por habitante havia aumentado cerca de sete vezes em relação ao nível prevalecente em 1930. 
Evidentemente, tal trajetória não se deu de maneira linear ${ }^{1}$; também aqui de modo simplificado, três grandes etapas podem ser identificadas:

1. Os anos que transcorrem entre 1930 e 1950, que representaram a fase inicial da criação das forças produtivas especificamente capitalistas e da constituição do modo de produção especificamente capitalista no país; é um período de "industrialização restringida", pois os segmentos que compõem o setor de bens de capital ainda não se faziam presentes. Corresponde, na linguagem convencional, a uma etapa de transição entre um modelo "primário-exportador" e outro, cujo centro dinâmico passou a ser a indústria.

2. A segunda etapa (1950-1963), que se caracterizou pela implantação da indústria de bens de consumo duráveis e dos bens de capital a ela acoplados, sob liderança das grandes corporações multinacionais e forte presença do Estado na produção de insumos básicos e no planejamento econômico.

3. A terceira etapa, inscrita entre 1964 e 1980, que foi marcada pelo chamado "milagre econômico"2 e pela implantação de importantes setores industriais e de insumos básicos, com a execução do Segundo Plano Nacional de Desenvolvimento (II PND).

Para além das altas taxas de crescimento desses 50 anos, há importantes diferenças, no que tange à política macroeconômica, entre os processos de desenvolvimento verificados na segunda e na terceira etapas. Grosso modo, podese dizer que o início da década de 1960 marcou o esgotamento de um processo de crescimento econômico, no qual não foi necessária a ação de instrumentos efetivos de gestão macroeconômica. Até então, a única política macroeconômica efetivamente mobilizada em prol do desenvolvimento havia sido a cambial; outras políticas, como a monetária e a fiscal, possuíam papel praticamente irrelevante. Isto era reflexo, fundamentalmente, do atraso do capitalismo brasileiro, no qual estavam ausentes algumas instituições-chave, como banco central e mercados de capitais efetivamente constituídos, bem como da fragilidade fiscal do Estado brasileiro, manifesta nos impostos de má qualidade e em uma carga tributária baixíssima, vis à vis as necessidades

1 Não cabe, tendo em vista o propósito desse texto, maiores considerações sobre as transformações do regime político do país. Não se deve esquecer, entretanto, que o país viveu sob dois regimes autoritários (1930-1945 e 1964-1985) e, entre eles, um intermezzo democrático, sob a vigência da Carta Constitucional de 1946. Também não se pode esquecer que o quadro internacional e que alguns dos fatores determinantes para o desenvolvimento das forças produtivas variaram intensamente no período.

2 Em 1973, registrou-se a mais alta taxa de variação real do PIB brasileiro (13,9\%); a média de crescimento anual, entre 1967 e 1973, foi da ordem de 10 por cento. 
existentes; tais características eram uma herança do modelo anterior, usualmente chamado "primário-exportador". As resultantes macroeconômicas desse modelo de crescimento foram os fortes desequilíbrios associados a problemas inflacionários e de balanço de pagamentos, característicos do final dos anos 1950.

Já a terceira etapa se deu, em contrapartida, sob a égide de profundas reformas, nos planos macro e microeconômico, levadas a termo nos primeiros anos do regime militar instaurado em 1964 e que tiveram como ponto de partida o Plano de Ação Econômica do Governo (PAEG), implementado no período 1964-1966. As reformas financeira, fiscal e tributária, entre outras, concretizadas em tão curto espaço de tempo, graças ao contexto autoritário então vigente, dotaram o Estado brasileiro de um vasto e até então inédito instrumental de gestão macroeconômica, que foi mobilizado para promover o crescimento acelerado.

O esgotamento desse modelo deu-se em função das sucessivas crises internacionais (crise monetária e ruptura do sistema de Bretton Woods, choques do petróleo e choque dos juros norte-americanos) que, ao final da década de 1970, solaparam a economia brasileira, dada sua exposição excessiva ao endividamento externo, aprofundada durante o governo Geisel, no âmbito do II PND, e afastaram da rota da periferia o investimento das corporações multinacionais, que exerciam a liderança dinâmica na estrutura produtiva do país. Estas são as raízes da severa crise por que passaria o país em sua década perdida, na qual ocorreram duas moratórias, estagnação econômica e um processo de alta inflação crônica.

Não se pode deixar de formular, nessa altura, a seguinte conjectura: das três etapas consideradas, e descartando-se a primeira (1930-1950), identificada como de transição para o desenvolvimento do capitalismo industrial no Brasil, em uma delas, qual seja, 1950-1963, prevaleceu uma estratégia de desenvolvimento baseada em crescimento acelerado e transformação da estrutura produtiva, sem gestão macroeconômica, mas com democracia política; na outra, entre 1964 e 1980, a estratégia anterior aprofundou-se com a criação dos instrumentos de política macroeconômica, porém num contexto autoritário.

\section{2 | Três Décadas de Lento Crescimento: 1980-2009}

Finda essa longa trajetória de crescimento, inicia-se uma fase que, em oposição à anterior, correspondeu a 30 anos de lento crescimento (ou mesmo, em alguns momentos, de semiestagnação). Para fins de análise, serão considerados, nessa trajetória recente, dois subperíodos:

1) 1980-1994, marcado pela transição democrática e pela estagnação econômica associada à crise do modelo anterior; 
$2^{\circ}$ ) pós-1994, caracterizado pela implementação de novo regime macroeconômico e por baixo crescimento econômico.

Em mais detalhes, o primeiro período caracterizou-se pela recondução, lenta e gradual, do Brasil à democracia e por graves desequilíbrios macroeconômicos - como elevada aceleração inflacionária e crescente fragilização do Estado brasileiro, do ponto de vista externo (endividamento) e interno (fiscal e financeiro) - decorrentes do esgotamento do modelo anterior.

O segundo período - cujo marco zero é a implementação do Plano Real, em 1994, quando já havia sido concluída a bem-sucedida recondução política do país para a democracia - caracteriza-se pela ampliação do alcance dos instrumentos de política macroeconômica, permitida pelas condições de "normalidade", decorrentes do sucesso da estratégia de estabilização de preços. Desde então, esse instrumental passa a ser mobilizado na busca quase exclusiva da estabilidade de preços, identificada como condição primordial para o desenvolvimento.

A estabilização dos preços pós-1994, contudo, embora importante, não conseguiu devolver ao país o ritmo de crescimento característico do período 1950-1980. Em mais detalhes, pode-se constatar que o período 1950-1980 caracterizou-se por um crescimento médio da ordem de 7,4\% ao ano, enquanto no período 1981-2009, a taxa média de crescimento do PIB atinge somente pouco mais de um terço desse valor (2,4\% ao ano). Mesmo considerando o subperíodo 2004-2009, a taxa média de crescimento econômico (4,0\% ao ano) ainda é baixa para um país que aspira atingir a condição de nação desenvolvida.

Essas constatações expressam um fato fundamental por suas implicações quanto aos limites da atual política econômica: a economia brasileira evoluiu sob um regime de alto crescimento entre 1950 e 1980, abrangendo os períodos do Plano de Metas (1951-1961), do "milagre econômico" (1967-1973) e do II PND (1975-1979), enquanto, a partir dos anos 1980, desviou-se dessa trajetória de expansão acelerada, passando a operar sob um regime de baixo crescimento, mesmo após controlar a inflação.

Embora as causas para o ingresso nessa trajetória de baixo crescimento não possam ser atribuídas apenas ao atual modelo econômico, não há como escapar à conclusão de que o mesmo vem-se mostrando incapaz de elevar a taxa média de crescimento da economia brasileira. Em outros termos, apesar de determinadas restrições estruturais terem sido equacionadas e superadas no período pós-estabilização de preços, a economia brasileira atual mostra-se ainda incapaz de gerar elevadas e sustentadas taxas de crescimento econômico, condição necessária para a promoção do desenvolvimento. 


\section{3 | A POLÍTICA ECONÔMICA E O DEBATE ATUAL}

O regime de política econômica atualmente vigente no Brasil alicerça-se em três pressupostos básicos:

- regime de metas de inflação (RMI);

- sistema de câmbio flutuante;

- política fiscal baseada na obtenção de metas de superávit primário.

Esse regime, que vigora desde o ano de 1999, distingue-se pela proeminência concedida à estabilidade de preços. Consequentemente, a obtenção de elevadas taxas de crescimento econômico e de expansão do emprego tem sido relegada a segundo plano, uma vez que não integram os objetivos explícitos da política monetária. Sempre que há conflito entre o controle da inflação e o crescimento econômico, opta-se pela estabilidade de preços em detrimento do crescimento, sob a alegação, jamais confirmada, de que o produto potencial ou de longo prazo não será comprometido por essa decisão. Contrariamente a essa crença, avança-se aqui a hipótese de que o atual regime de política econômica constitui um entrave ao desenvolvimento socioeconômico do país. As principais características e implicações desse regime para a economia brasileira devem, portanto, ser discutidas, uma vez que se constituem em ponto essencial para o desenho dos cenários futuros.

Uma ideia-chave, implícita no regime de política econômica vigente, é que, uma vez alcançada a estabilidade de preços, o crescimento econômico sustentado será necessariamente sua resultante macroeconômica. Pressupõe-se que políticas monetárias restritivas, com taxas elevadas de juros, teriam efeitos reais significativos apenas a curto prazo, não afetando a trajetória de crescimento a longo prazo do produto potencial. Os proponentes da atual política econômica justificam a ênfase concedida à estabilidade de preços com base em um suposto consenso, contrário ao uso discricionário dos instrumentos de política econômica - particularmente a política monetária - com intuito de reduzir o desemprego, como propõe a tradição macroeconômica de inspiração keynesiana.

De fato, é amplamente difundida a crença de que reduzidos níveis de inflação são precondição para a sustentabilidade do crescimento econômico. De acordo com essa crença, a estabilidade de preços é promotora do bem-estar social e deve, por isso, ser perseguida. No caso brasileiro, o fato de o país ter experimentado um longo período de alta inflação crônica contribui para a aceitação, quase que incondicional, dessa concepção por boa parte da academia, dos formadores de opinião e do público em geral. Em consequência, pouca atenção tem sido dada aos custos derivados da manutenção da estabilidade de preços decorrentes de uma política monetária conservadora. São, no entanto, exatamente as consequências dessa política que devem ser discutidas. 
De fato, a política monetária tem sido caracterizada por um excesso de rigidez. No Gráfico 1, encontram-se as taxas básicas de juros reais observadas no país, nas economias emergentes e na Turquia, que disputa com o Brasil o primeiro lugar no ranking das maiores taxas de juros do mundo. No período de 1995 a 2008, a taxa de juros real no Brasil foi, sistemática e consideravelmente, superior à prevalecente nos países emergentes (incluindo o Brasil). À exceção dos anos de 2001 e 2002, os juros no país foram absurdamente maiores do que os verificados no grupo dos emergentes. Entre os anos de 1995 e 2008, a taxa de juros média no Brasil foi bastante superior à taxa média da Turquia.

Considerando suas consequências negativas, pode-se afirmar que a rigidez monetária é uma das razões - ainda que não a única - para o fraco desempenho da economia brasileira entre 1995 e 2008. O PIB real cresceu abaixo de 6\% em todos esses anos, ficando acima de 5\% em apenas três ocasiões: 2004, 2007 e 2008. Tal resultado revela-se ainda pior quando comparado com os demais países emergentes que têm crescido a taxas superiores e de forma sustentável (ver Gráfico 2).

A taxa de câmbio, por sua vez, também tende a se reduzir, em resposta a um aumento na taxa Selic ${ }^{3}$. O elevado diferencial entre a taxa de juros doméstica e a praticada no exterior contribui para o expressivo processo de valorização do real, verificado a partir de 2003. Assim, o real é uma das moedas que mais se valorizou recentemente: no ano de 2008, a taxa de câmbio média aproximou-se do valor verificado em 1999 (ver Gráfico 3).

Essa valorização cambial é temerária por desestimular exportações e estimular importações - o que, de um lado, contribui para limitar o crescimento do PIB e, por outro, torna o financiamento do balanço de pagamentos dependente da entrada de capitais, sempre a curto prazo, de caráter especulativo e essencialmente voláteis.

Gráfico 01. Taxa Básica de Juros (\% a.a.) - Brasil, Turquia e Países Emergentes (1995-2008)

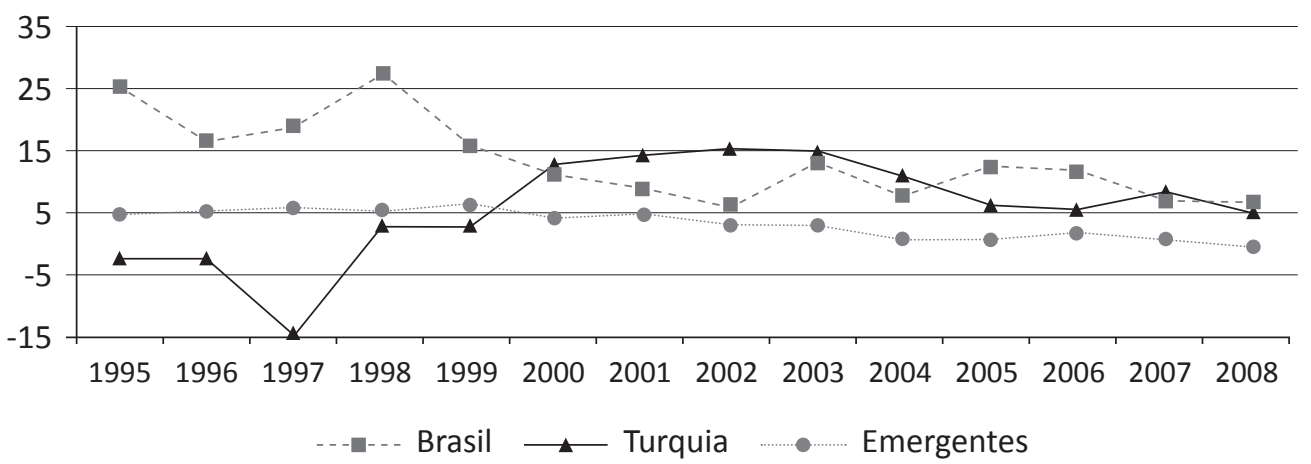

Fonte: World Economic Outlook e International Financial Stastictics.

3 Selic é a sigla que designa o Sistema Especial de Liquidação e de Custódia. 
Gráfico 02. Taxas de crescimento econômico comparadas (1995-2008)

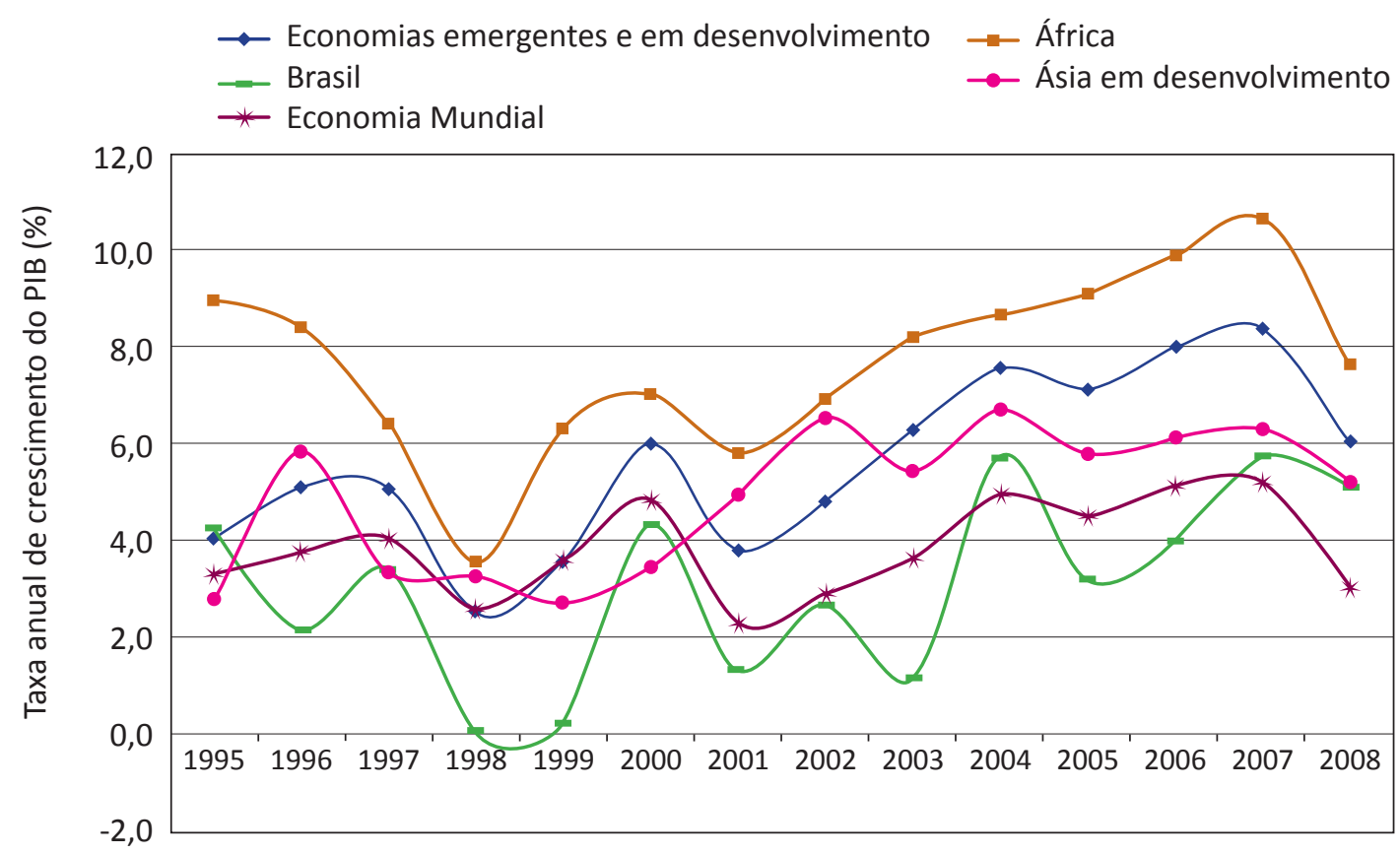

Fonte: World Economic Outlook - FMI (2009).

Nota: Séries suavizadas.

Gráfico 03. Taxas de Cambio Média - Brasil (1995-2009)

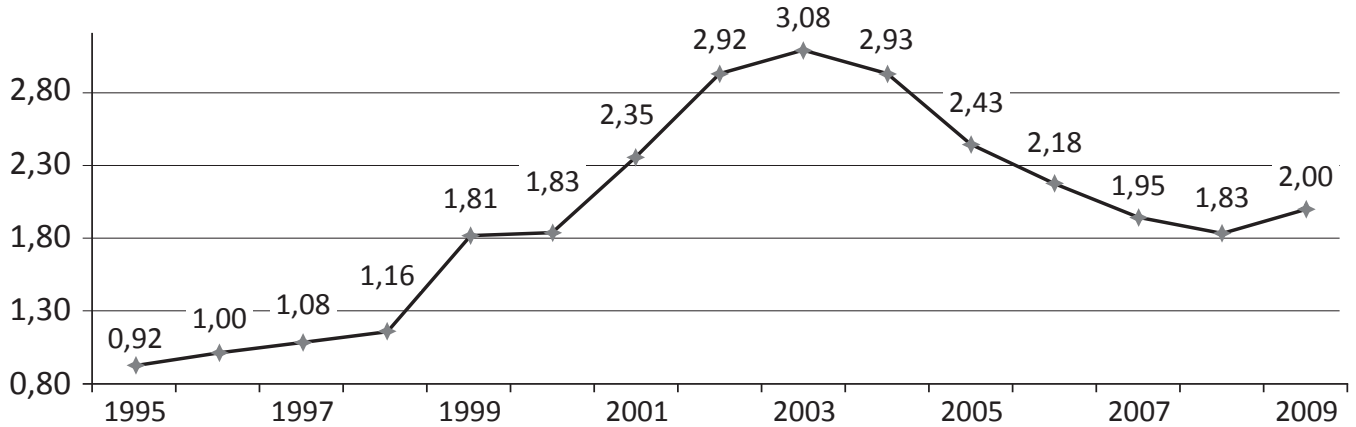

Fonte: Banco Central do Brasil.

Finalmente, a evolução das contas públicas tem sido fortemente influenciada pela política monetária. É inequívoco o impacto negativo da política monetária sobre as contas públicas: a despeito da obtenção de superávits primários robustos, da ordem de 4,0\% do PIB em média, verificaram-se déficits nominais entre 
1,5\% e 5,8\% do PIB, entre os anos de 1999 e 2009. Ou seja, a despesa com o pagamento de juros da dívida pública foi, sistemática e consideravelmente, superior aos superávits verificados nas contas primárias do setor público. É nesse sentido que tem ocorrido uma dominância monetária: a política monetária tem impactado fortemente e de maneira negativa as contas públicas.

A dominância monetária é exacerbada por uma peculiaridade da dívida pública brasileira: a existência de títulos indexados à taxa básica de juros. As Letras Financeiras do Tesouro Nacional (LFT) são títulos pós-fixados que evoluem de acordo com a taxa Selic. Como as LFT constituem parcela relevante do estoque da dívida pública mobiliária federal interna - até ultrapassando a metade do total como, por exemplo, em dezembro de 2005, quando alcançou 52,0\% — a manutenção da taxa Selic em níveis muitos elevados resulta em um custo financeiro igualmente alto: a despesa com o pagamento de juros da dívida pública foi, em média, superior a 7\% do PIB, no período de 1995 a 2008, tendo alcançado o pico de 9,4\%, em 2003 (ver Tabela 1).

Os desdobramentos deste regime macroeconômico para o dinamismo da economia brasileira podem ser apreendidos, para o período 1995-2008, pelo baixo desempenho relativo da economia brasileira vis à vis à economia mundial. Ilustrativamente, as taxas de crescimento do país superaram a média mundial somente em 2004 e 2008. Além disso, quando comparada à africana, por exemplo, a economia brasileira também apresentou baixo desempenho econômico, superando o crescimento deste grupo de países apenas no ano de 2000. O cenário torna-se mais grave quando o Brasil é comparado com o conjunto das economias em desenvolvimento e, em especial, com a Ásia em desenvolvimento: ao longo de todo o período, o país cresceu a taxas sistematicamente menores que aquelas verificadas para os dois conjuntos de economias. Do exposto, não há como recusar a afirmativa anterior quanto ao papel desempenhado pelo atual regime de política econômica: ele é um dos principais fatores para explicar o fraco desempenho macroeconômico apresentado pelo país. 
Tabela 01. Indicadores Selecionados das Contas Públicas (\% do PIB), Brasil, 1995-2008

\begin{tabular}{l|c|c|c}
\hline Ano & Superávit Primário & Despesa de Juros & Déficit Nominal \\
\hline 1995 & $-0,3$ & 6,8 & 6,5 \\
\hline 1996 & $-0,1$ & 5,7 & 5,8 \\
\hline 1997 & $-0,9$ & 5,0 & 5,9 \\
\hline 1998 & 0,0 & 7,5 & 7,5 \\
\hline 1999 & 3,3 & 9,1 & 5,8 \\
\hline 2000 & 3,5 & 7,1 & 3,6 \\
\hline 2001 & 3,7 & 7,2 & 3,5 \\
\hline 2002 & 4,0 & 8,3 & 4,3 \\
\hline 2003 & 4,3 & 9,4 & 5,1 \\
\hline 2004 & 4,2 & 6,6 & 2,4 \\
\hline 2005 & 4,4 & 7,3 & 3,0 \\
\hline 2006 & 3,9 & 6,9 & 3,0 \\
\hline 2007 & 4,0 & 6,2 & 2,2 \\
\hline 2008 & 4,1 & 5,6 & 1,5 \\
\hline
\end{tabular}

Fonte: Banco Central do Brasil.

Cabe, no entanto, um reparo: para um observador atento, houve nuances na condução da política econômica, que permitem identificar novos elementos na gestão macroeconômica, em particular após o espocar da grande crise econômica internacional, cujos efeitos se fizeram sentir de maneira mais aguda em 2008. A observação desses elementos está a sugerir o fato de que uma tentativa de reorientação do regime, em moldes mais compatíveis com uma perspectiva de crescimento econômico e promoção do emprego, está em curso. O exemplo mais claro foi o uso da política fiscal - tanto pela manutenção e ampliação dos níveis de gasto público, quanto pela utilização de incentivos tributários na produção e consumo de bens de consumo duráveis - como ferramenta anticíclica para atenuar os efeitos da crise. Vale também destacar que, ainda no governo anterior (2003-2010), tentou-se (com pouco êxito) impor algum controle à saída de capitais através da majoração da alíquota do Imposto sobre Operações Financeiras (IOF), com o objetivo de se reduzir a volatilidade cambial.

Já no atual governo, há pelo menos três novos aspectos que confirmam a ideia de que está em curso uma inflexão na política macroeconômica, em particular em relação à política monetária implementada pelo Banco Central: uma melhor coordenação entre as autoridades monetárias e outros ministérios econômicos, 
especialmente o Ministério da Fazenda; o uso de outros mecanismos de controle monetário, como as chamadas "medidas macroprudenciais", concernentes ao controle do crédito e do compulsório bancário; e o fato, evidenciado nas últimas decisões e nas atas das reuniões do Comitê de Política Monetária (Copom), de que objetivos vinculados à economia real, como sustentação dos níveis de produto e emprego, vêm sendo levados em conta, em paralelo ao controle da inflação.

É interessante destacar que o discurso oficial confirma essa hipótese. Em evento realizado em fins de 2011, no BNDES, o secretário-executivo do Ministério da Fazenda, Nelson Barbosa, afirmou que "a estratégia de desenvolvimento do Brasil baseou-se em três fatores estruturais: aumento das exportações de commodities; bônus demográfico, que propiciou o crescimento da população economicamente ativa; e democracia, com a consequente redução da incerteza jurisdicional".

Tal abordagem é reforçada em Serrano \& Summa (2011), para quem "a interação entre grandes mudanças nas condições externas com as quais a economia brasileira se defrontava (desde 2003) e pequenas mudanças na orientação da política econômica doméstica explica a melhora no controle inflacionário, a recuperação das taxas de crescimento do PIB e a melhora na distribuição de renda e pobreza da segunda metade da década passada”.

Sem embargo, é preciso ter claro que uma readequação nos rumos da política macroeconômica tem de necessariamente ser pactuada e implementada de maneira gradual, além de permanentemente discutida pela sociedade, que não aceitará aventuras que ponham em risco a estabilidade de preços, considerada uma das mais relevantes conquistas recentes da sociedade brasileira.

É inegável que o Plano Real, lançado em 1994, foi bem-sucedido no combate ao regime de inflação alta e crônica. Falta, porém, uma etapa do processo de estabilização, que incorpore uma flexibilização responsável da política monetária, que não ameace a estabilidade de preços e valha-se de instrumentos auxiliares de controle da inflação. Poderemos assim caminhar para patamares de taxa básica de juros mais próximos aos verificados no resto do mundo - sem o que a economia brasileira continuará a depender de ventos internacionais favoráveis para aliviar sua restrição externa.

É fundamental, portanto, que se aprofunde a reflexão e o debate em torno de uma agenda de pesquisa que dê subsídios à definição de um regime macroeconômico comprometido com mudanças estruturais. Esse regime deve contemplar uma efetiva coordenação entre as políticas monetária, financeira, cambial e fiscal, e fazer parte de uma estratégia de desenvolvimento que priorize o pleno emprego e a obtenção de elevadas taxas de crescimento, consistentes com a robustez do balanço de pagamentos e com a estabilidade de preços. 


\section{4 | ESTUDOS PROSPECTIVOS}

Estudos prospectivos voltados para a construção de cenários têm sido uma ferramenta largamente utilizada para o planejamento estratégico, tanto por parte de empresas quanto por governos, na tentativa de prever riscos e dotar o processo decisório de bases conceituais mais sólidas.

As condições em que o mundo emergiu da II Guerra Mundial, com a derrota do nazi-fascismo e o papel desempenhado pela União Soviética, levaram vários países capitalistas do Ocidente a adotar modelos de planejamento (global ou setorial), o mais conspícuo exemplo sendo o da França. Ao mesmo tempo, nos Estados Unidos, a Rand Corporation desenvolveu, desde então, técnicas para aplicação desse instrumento em empresas, elaborando a primeira metodologia de construção de cenários.

Foi, no entanto, em 1967, com a publicação de The year 2000, de autoria de Hermann Kahn ${ }^{4}$ e Anthony J.Wiener, que os estudos prospectivos ganharam notoriedade, ainda que associados à ideia de futurologia. Em seu livro, Kahn e Wiener fazem previsões de como seria o mundo na virada para o Século XXI ${ }^{5}$. Alguns exemplos das estimativas ali apresentadas são significativos: em dólares de 1965, os Estados Unidos deveriam ter chegado ao ano 2.000 com um PNB per capita variando entre US 4.760 e US\$12.420; e o PNB per capita do Brasil deveria estar situado entre US\$ 117 e US\$950, dependendo, em cada caso, da taxa de crescimento econômico. Para os leitores brasileiros, o ponto mais crítico dessas previsões era a afirmação de que o Brasil levaria 130 anos para atingir o patamar de PNB per capita da população norte-americana ${ }^{6}$.

O exemplo é curioso porque essas previsões foram feitas em período anterior à década de 1970, quando se sucederam os choques do petróleo, a crise monetária internacional e a ruptura do sistema de Bretton Woods - e também anterior a imensa turbulência que o sistema mundial enfrentou nos anos 80 e 90 do século passado. Pois bem: mesmo assim, o PIB per capita do Brasil, em 2001, era de US\$ 3.186,10 (em dólares correntes), valor esse que atingiu a marca de US\$ 10.813,98 em 2010. Também os Estados Unidos chegaram à virada do século com um PNB per capita da ordem de US\$ $34 \mathrm{mil}^{7}$.

4 Kahn trabalhou, após a II Guerra Mundial, na Rand Corporation, de onde saiu, em 1961, para fundar o Hudson Institute, que dirigiu até sua morte, em 1983.

5 A edição brasileira foi prefaciada por Roberto Campos, que afirmou ter ficado deprimido com as previsões ali apresentadas. Kahn, H e Wiener, A.J.: O ano 2000: uma estrutura para especulação sobre os próximos trinta e três anos, SP: Melhoramentos/USP, 1968.

6 Os autores consideravam constante a taxa de crescimento populacional do país, que era, na ocasião, superior a $3 \%$ ao ano.

7 Mesmo levando em conta a diferença entre PIB e PNB (este último inclui a renda líquida do exterior) e a evolução do valor do dólar no período, as previsões do Hudson Institute ficaram muito aquém da realidade. 
Vale lembrar ainda que, pouco depois (1972), foi divulgado pelo Clube de Roma o estudo intitulado Os limites do crescimento, que apresentava cenários para a economia mundial e o meio ambiente, concluindo que o planeta não suportaria a pressão gerada pelo crescimento sobre os recursos naturais e o meio ambiente ${ }^{8}$.

O aparente fracasso dos modelos de previsão, no entanto, não desanimou os construtores de cenários. Ao contrário, eles refinaram suas técnicas e diversificaram sua metodologia. Apenas à guisa de exemplo, poderíamos apontar alguns dos principais modelos de construção de cenários em uso atualmente:

- Global Link Network (GBN) e Peter Schwartz9 (1988), que o desenvolvem em oito etapas:

- identificação da questão principal;

- identificação dos fatores-chave (microambiente);

- identificação das forças motrizes (macroambiente);

- ranking das incertezas críticas;

- definição da lógica dos cenários;

- descrição dos cenários;

- seleção de indicadores e sinalizadores principais;

- análise das implicações e opções.

- Porter $^{10}$ (1992), que o organiza em sete etapas:

- estabelecimento dos propósitos do estudo, amplitude e ambiente temporal;

- análise da estrutura industrial;

- definição das fontes de incertezas;

- determinação dos cenários;

- consistência dos cenários;

8 Esse estudo foi elaborado por uma equipe do Massachusetts Institute of Technology (MIT), coordenada por Dana Meadows, por encomenda do Clube de Roma. O Clube de Roma, fundado em 1968, pelo empresário italiano Aurélio Peccei e pelo cientista escocês Alexandre King, existe até hoje.

9 Peter Schwatz é especialista em estudos prospectivos e construção de cenários, sendo um dos fundadores da Global Business Network (GNT).

10 Michael Porter é professor Harvard Business School. 
- análise das estratégias dos concorrentes;

- elaboração de estratégias competitivas

- Michel Godet11 (1993), estruturado em seis etapas:

- delimitação do sistema e do ambiente;

- análise estrutural do sistema e do ambiente e análise retrospectiva do ambiente e da situação existente;

- seleção dos condicionantes do futuro;

- geração de cenários alternativos;

- testes de consistência;

- estabelecimento de planos e estratégias e de mecanismos de monitoramento.

- Grumbach ${ }^{12}$ (1997), que o divide em três fases:

- conhecimento do problema;

- construção e identificação de variáveis alternativas;

- avaliação e interpretação das variáveis alternativas existentes para a tomada de decisão.

\section{1 | Estudos Prospectivos Recentes}

Também no Brasil, o impacto causado pelo livro de Kahn e Wiener foi grande, tendo sido o Professor Mario Henrique Simonsen o primeiro a publicar, em 1969, uma resposta em que apontava para cenários mais otimistas, baseados na adoção de taxas de crescimento mais vigorosas e de menores taxas de crescimento populacional.

Ainda que não se possa dizer que a iniciativa do Professor Mario Henrique tenha inaugurado uma tendência de estudos prospectivos e construção de cenários, o fato é que inúmeros são os trabalhos produzidos desde então, seja voltados para o ambiente macroeconômico, seja para estudos setoriais ou regionais, seja para o planejamento estratégico de empresas. O próprio Simonsen retornou ao tema, pouco depois, publicando novo estudo (SIMONSEN, 1975).

11 Michel Godet é professor do Conservatoire National des Arts e Métiers de Paris.

12 Raul Grumbach é brasileiro, consultor de empresas e especialista em cenários prospectivos. 
Considerando apenas os que foram publicados em período recente, podem-se destacar o Plano Plurianual (PPA) do Governo Federal 2012-2015 (BRASIL, MPOG, 2011) e Brasil 2022 (BRASIL. SAE, 2010), além de trabalhos de autores como Giambiagi e Porto (2011), Cardoso Júnior (2010), Werneck Vianna (2009), Giambiagi e Barros (2009), Giambiagi e Pinheiro (2006), Porto (2005) e Velloso (2005).

Deve-se observar que esses trabalhos não só adotam metodologias diversas, como poucos deles possuem uma visão crítica dos limites e das possibilidades da técnica de construção de cenários prospectivos; alguns deles apresentam projeções numéricas sem detalhar o método que seguiram para alcançá-las e outros não apresentam nenhuma projeção numérica, limitando-se a realizar uma discussão mais conceitual sobre o desenvolvimento em longo prazo.

Preliminarmente, pode-se afirmar que a discussão mais interessante sobre os limites e possibilidades da técnica de cenários prospectivos é feita pelo Professor Mário Henrique Simonsen; em seu livro, ademais, ele faz estimativas com números e defende seus pontos de vista relacionados a questões de ajuste fiscal, eficiência de gastos etc.

Fabio Giambiagi, Octávio de Barros, Claudio Porto e Antonio Palocci (este último em sua intervenção no XVII Fórum Nacional) também consideram as restrições à técnica de cenários, mas defendem sua importância; todos eles apresentam estimativas com números concretos, vinculadas à defesa de políticas econômicas ortodoxas. Porto e Giambiagi constroem cenários baseados em diferentes hipóteses para o desempenho da economia a longo prazo (cenário otimista, cenário pessimista e cenário intermediário). O Plano Plurianual e o Plano Brasil 2022 da Secretaria de Assuntos Estratégicos apresentam uma visão otimista do futuro, mas não há neles nenhum detalhamento da metodologia adotada nem dos limites dessas estimativas. Quanto aos trabalhos consultados do Instituto de Pesquisa Econômica Aplicada (Ipea), pode-se observar que não visam a construção de cenários prospectivos nem apresentam estimativas numéricas para o desempenho futuro da economia; a discussão que realizam é sobre os limites e desafios estruturais ao desenvolvimento econômico do país.

Algumas observações adicionais podem ser feitas, a partir da leitura desses textos. Há algumas questões recorrentes, relacionadas a temas das políticas macroeconômicas em curso. Grande parte da literatura reconhece os avanços em termos de estabilidade de preços, redução da desigualdade de renda, fortalecimento do mercado interno e redução da vulnerabilidade externa como fatores favoráveis às possibilidades futuras de desenvolvimento. Por outro lado, há uma "agenda inconclusa", frequentemente sugerida, que gira em torno da necessidade do equilíbrio fiscal e do aumento da poupança doméstica como elementos fundamentais para que uma trajetória de desenvolvimento seja de fato alcançada. 
Delfim Netto, por exemplo, afirma que "a única fórmula possível para que a 'agenda fiscal' dê sua contribuição decisiva para a política econômica de aceleração do desenvolvimento econômico e social atinja (digamos em 2018) uma relação carga tributária/PIB de 30\% será o compromisso do poder incumbente eleito em 2010 de realizar um longo, paciente, responsável e cuidadoso programa de: controle do aumento das despesas do seu custeio propriamente dito; aumento do controle e da eficácia das políticas sociais financiadas com as transferências e rápida melhoria qualitativa de toda a administração pública" (BARROS \& GIAMBIAGI, 2009).

Assim, apesar da contínua geração de superávits primários durante a última década, alguns autores consideram que o país não poupou como deveria, mesmo durante o chamado "ciclo dourado". A má qualidade e o excesso do gasto público seriam então os grandes responsáveis pela baixa poupança doméstica, que por sua vez, aparece como o grande entrave para o crescimento.

Sobre este ponto, Octávio de Barros e Fabio Giambiagi argumentam que "a baixa taxa de poupança doméstica (cerca de 17\% do PIB) segue sendo o maior entrave ao crescimento sustentado brasileiro, criando limites à expansão da taxa de investimento. Este é o grande desafio macroeconômico do país: como viabilizar a ampliação da taxa de investimento para algo entre $22 \%$ e $24 \%$ do PIB, idealmente, nos próximos anos" (BARROS \& GIAMBIAGI, 2009).

Seguindo a mesma argumentação, Antonio Palocci, em sua intervenção no XVII Fórum Nacional, defende que um ajuste fiscal limitado a um governo de quatro anos é estratégia insuficiente para se construir um cenário de longo prazo mais favorável em termos de desenvolvimento econômico. Para tanto, o esforço fiscal seria necessário por, pelo menos, mais uma década (VELLOSO, 2005).

Giambiagi \& Pinheiro (2006), por sua vez, através da simulação de mudanças consideradas prioritárias nas contas públicas, traçam um cenário para 2015 centrado na diminuição da razão dívida/PIB para um patamar consistente com padrões internacionais, afirmando que é viável adotar um esquema fiscal de médio e longo prazo que atinja os objetivos propostos.

Ao contrário dessa visão, no entanto, parte da literatura assinala a importância de um novo paradigma fiscal que reverta em definitivo a política de geração de superávit fiscal e recupere o papel do Estado como indutor do desenvolvimento. Os trabalhos consultados do IPEA, por exemplo, questionam o uso dos juros elevados como instrumento único de combate à inflação e advogam a necessidade de uma articulação entre as políticas macroeconômicas que as vincule, também, ao objetivo do desenvolvimento econômico e não apenas ao de estabilidade de preços. Apesar de não construírem cenários prospectivos com estimações numéricas, estes trabalhos enfrentam a discussão em torno dos limites e desafios estruturais ao desenvolvimento (IPEA, 2010). 
Com relação a projeções econômicas com estimativas numéricas a longo prazo, alguns autores trabalham com a técnica de construção de cenários alternativos diversos, em geral um cenário otimista, um pessimista e um ou mais cenários intermediários (PORTO, 2007; GIAMBIAGI \& PORTO, 2011). Os limites dessas estimativas, em termos de subjetivismo, risco e incerteza, não são ignorados, mas considera-se que, apesar deles, é possível reduzir a percepção a respeito do futuro e melhorar a qualidade de decisões estratégicas, tornando-as mais controláveis ou avaliáveis. Segundo esses autores, busca-se escapar do determinismo e "estabelecer uma sucessão lógica de eventos, de sorte que, partindo-se do presente (ou de uma dada situação), se visualize como se poderá chegar passo a passo a uma situação futura" (PORTO, 2007).

Seguindo essa técnica, Giambiagi \& Porto (2011) constroem quatro cenários de longo prazo para o Brasil, incluindo estimativas para o crescimento e para as taxas de poupança e de investimento. As diferenças entre os cenários envolvem distintas condições sobre a inserção econômica do país no contexto global e sobre o peso do Estado na economia, por serem considerados os dois fatores mais relevantes na definição dos rumos possíveis para o país.

A necessidade de planejamento econômico no âmbito do governo federal também coloca a análise prospectiva como tema de documentos oficiais do governo, como o Plano Plurianual (PPA) e estudos da Secretaria de Planejamento Estratégico (SAE). Pode-se considerar que o ar otimista em torno de seus cenários futuros está ligado ao comprometimento com as políticas de desenvolvimento econômico que estão sendo levadas a cabo. A "visão de futuro" do PPA, por exemplo, é embasada a partir "das decisões soberanas que hoje podemos tomar" e da existência um governo comprometido com o "desenvolvimento econômico e social, orientado, antes de tudo, pela inclusão social” (PPA, 2011). O estudo da SAE sobre projeções para o Brasil em 2022, por sua vez, indica “um país em acelerado desenvolvimento sustentável” e afirma que "o Brasil será um Estado ainda mais soberano e cada vez mais democrático; uma sociedade mais justa e progressista” (SAE, 2010). São definidas metas para o centenário, associadas a estimativas para algumas variáveis econômicas. A metodologia e os limites dessas das estimações não são explorados, tampouco os caminhos pelos quais as metas serão atingidas.

De acordo com o estudo da SAE, “até 2022, estará plenamente consolidado o crescimento sustentável, com estabilidade da moeda e solidez das contas do Estado. A dívida pública estará próxima de 25\% do PIB, a dívida externa líquida será negativa, como já é hoje, e um grande desafio será aumentar a formação de capital, diversificar nossas exportações e ampliar nossa participação no comércio mundial. Haverá, em 2022, um número expressivo de empresas brasileiras com ação internacional, tanto exportadoras como investidoras, em todos os continentes e o Brasil terá alcançado a posição de quinta maior economia do mundo. (SAE, 2010) 
De modo geral, pode-se dizer que a literatura sobre cenários prospectivos converge para um ponto importante: uma sociedade pode escolher seu futuro dentre diversas alternativas e essa construção não é tarefa fácil. Qualquer previsão econômica de longo prazo está sujeita a considerável margem de erro e é permeada por incerteza fundamental. Mas esse exercício não é inútil. Sua utilidade reside na indicação das condições necessárias à obtenção dos objetivos da sociedade, sempre se levando em conta que história econômica é resultado da ação dos homens, de circunstâncias políticas e de constrangimentos estruturais.

\section{5 | CENÁRIOS NO HORIZONTE 2022-2030}

\section{1 | Considerações Iniciais}

As técnicas de construção de cenários, mencionadas anteriormente e usualmente adotadas em estudos prospectivos, desenvolvem-se através de etapas em que os cenários aparecem como resultado. As metodologias podem variar, conforme a orientação e a percepção teórica do autor, mas é sempre de uma dada combinação de fatores que resulta a construção do cenário.

As limitações dessas técnicas são evidentes e já foram destacadas por muitos autores. Simonsen (1972), quatro décadas atrás, já mostrava o erro em que incorrem os economistas quando formulam projeções para o comportamento da economia a longo prazo, baseadas em evidências tópicas a curto prazo. Rigorosamente falando, e considerando o que os economistas chamam de curto e de longo prazo, tal como os concebeu Alfred Marshall, em seu Principles of economics, não se pode cometer o equívoco de imaginar que uma tendência a longo prazo seja uma sequência de tendências a curto prazo; nem que, portanto, conhecendo-se as tendências que configuram uma dada conjuntura, seja possível estabelecer-se uma trajetória para o futuro a longo prazo.

O futuro é rigorosamente marcado pela incerteza - que não pode ser definida em termos probabilísticos. E essa incerteza é vivida pelos agentes econômicos de forma não necessariamente convergente e coordenada. Ao contrário, os agentes econômicos formam suas expectativas de modo diferenciado e agem de acordo com essas expectativas. Só que suas decisões (ou indecisões) acarretam custos, e, caso se frustrem, não haverá como corrigi-las a curto prazo. O comportamento dos agentes econômicos não se coaduna, portanto, com modelos de "expectativas adaptativas", nem , muito menos, com os de "expectativas racionais". A incerteza, de acordo com Keynes, é uma força endógena no funcionamento do sistema capitalista e é ela a responsável pela instabilidade própria a evolução da economia. 
Se observarmos a situação por que passa a economia mundial hoje - e, dentro dela, o estado em que se encontram os países centrais - podese facilmente concluir que os fatores de instabilidade são múltiplos, variados e de difícil previsibilidade. Mais do que isso, é difícil prever o impacto que cada um desses fatores terá nas economias da periferia, mesmo em um país com sólidos fundamentos macroeconômicos como o Brasil.

Exatamente por isso - e porque estudos prospectivos e construção de cenários devem ser utilizados como ferramentas para o planejamento e não como exercício de futurologia - foi adotado aqui o caminho inverso. O ponto de partida é a definição dos cenários — ou, mais precisamente, do cenário otimista — com o dimensionamento das variáveis relevantes; só depois é que foi estabelecida a trajetória que a economia brasileira deve percorrer para alcançá-los, em termos de decisões de política econômica e de fatos estruturais impactantes. Alternativamente ao cenário otimista, foram interpostos obstáculos (inclusive pela não-adoção de políticas adequadas) que impediriam a economia brasileira de atingir o cenário mais favorável.

A literatura consultada frisa a necessidade de mecanismos de acompanhamento e monitoramento, como instrumento indispensável para o bom uso das técnicas de estudos prospectivos e construção de cenários. Com a metodologia aqui adotada (que parte do cenário para a trajetória), mais importante ainda será o acompanhamento do desempenho das variáveis. Só assim poder-se-á garantir que fatos imprevistos, novos desenhos no quadro internacional ou fatores ligados à incerteza e à instabilidade inerentes ao capitalismo serão levados em conta e inseridos na prospecção do futuro. Só assim, essas ferramentas tornar-se-ão de fato úteis para o planejamento econômico.

\section{2 | Variáveis Relevantes}

São utilizadas as seguintes variáveis:

- PIB: valor e taxa de crescimento;

- Emprego e desemprego

- Renda per capita;

- Salário mínimo e rendimento médio do pessoal ocupado;

- Distribuição de renda: funcional e pessoal;

- Orçamento público e desempenho fiscal;

- Taxa de juros; 
- Taxa de câmbio e balanço de pagamentos;

- Taxa de inflação.

Tais variáveis compõem o que se poderia denominar a estrutura principal de um sistema macroeconômico de um país. Representam, ainda que de maneira incompleta, as dimensões fundamentais de uma economia moderna: moeda, câmbio, salários, tributos, gasto público.

Uma questão, no entanto, deve ser pontuada. Para quase todas essas variáveis, há uma distinção, que não é irrelevante, entre suas dimensões quantitativas e qualitativas. No que diz respeito à variável produto (PIB), por exemplo, tal distinção é crucial: ainda que o crescimento econômico (dimensão quantitativa) seja algo intrinsicamente positivo e constitua, portanto, um objetivo a ser buscado, sua mera consecução não garante à sociedade a realização de um objetivo maior, qual seja tornar-se desenvolvida (dimensão qualitativa). O exemplo brasileiro é paradigmático neste sentido: não obstante ter crescido a uma taxa anual média superior a 7\% entre 1950 e 1980, ao fim daquele período a economia brasileira, ainda que dramaticamente transformada, era ainda inegavelmente marcada por forte heterogeneidade estrutural, que impedia sua inclusão no rol dos países desenvolvidos.

A política macroeconômica em um país ainda em desenvolvimento, como o Brasil, deve, então, ser conduzida de maneira a se atingir dois objetivos. O primeiro é promover o crescimento econômico e fornecer condições para que este seja sustentado; isto envolve a adoção de políticas anticíclicas para atenuar os efeitos das flutuações econômicas na produção e no emprego, sem descuidar de outros aspectos igualmente importantes, como a estabilidade de preços e a ampliação da capacidade produtiva do país.

Tão importante ou mais, no entanto, é o objetivo de se buscar o desenvolvimento. E, para atingi-lo, são necessários investimentos maciços (públicos e privados) ao longo do tempo em saúde, educação e infraestrutura, com vistas a garantir o bem-estar de toda a população e a igualdade de oportunidades - além de investimentos, também de largo vulto, em ciência e tecnologia, possam, associados a políticas industriais e agrícolas, converter-se em fatores de impulso e dinamismo para os setores produtivos. O mais importante desafio que se apresenta é, portanto, tentar conciliar esses dois objetivos de tal forma que a gestão da política macroeconômica não cerceie as possibilidades de desenvolvimento econômico e social.

Dito isto, cabe uma breve exposição sobre as principais variáveis consideradas. O Produto Interno Bruto (PIB) representa a soma (em valores monetários) de todos os bens e serviços finais produzidos numa determinada região (países, 
estados, cidades), durante um período determinado (mês, trimestre, ano etc.). O PIB é um dos indicadores mais utilizados em macroeconomia com o objetivo de mensurar a atividade econômica.

$\mathrm{Na}$ contagem do PIB, consideram-se apenas bens e serviços finais, excluindo da conta todos os bens de consumo de intermediário. Isso é feito com o intuito de evitar o problema da dupla contagem, quando valores gerados na cadeia de produção aparecem contados duas vezes na soma do PIB.

Há três maneiras de se efetuar a mensuração do PIB: pela ótica da demanda, da oferta e do rendimento.

\subsection{1 | Ótica da demanda}

Na ótica da demanda, o valor do PIB é calculado a partir das despesas efetuadas pelos diversos agentes econômicos em bens e serviços para utilização final (isto é, aqueles bens e serviços que não vão servir de consumo intermediário na produção de outros bens e serviços). Nessa ótica, o PIB corresponde à demanda interna, que inclui a despesa das famílias em bens de consumo (consumo privado, C), a despesa do governo em bens de consumo (consumo público, G), a despesa das empresas em investimento (I), tanto em bens de capital (formação bruta de capital fixo, FBCF), quanto na aquisição de matérias-primas e produtos. A demanda interna inclui tanto os bens que foram produzidos no país quanto os que foram produzidos externamente (bens importados, M), e que, portanto, não devem ser incluídos no PIB. Por outro lado, há bens que devem ser incluídos no PIB, mas que são demandados externamente (as exportações, $\mathrm{X}$ ), e que por isso não estão incluídos na procura interna. Assim, na ótica da demanda o PIB é calculado a partir da soma de todas essas componentes:

$$
\mathrm{PIB}=\mathrm{C}+\mathrm{I}+\mathrm{G}+\mathrm{X}-\mathrm{M}
$$

(sendo I igual à formação bruta de capital fixo [FBCF] mais a variação nos estoques $[\triangle \mathrm{EST}])$.

\subsection{2 | Ótica da oferta}

Na ótica da oferta, o valor do PIB é calculado a partir do valor gerado em cada uma das empresas que operam na economia. Esse valor gerado é o VAB (valor adicionado bruto), a diferença entre o valor da produção e os consumos intermédios de cada empresa. Conhecendo o VAB de cada empresa, pode-se calcular o PIB como a soma de todos os VABs das empresas dessa economia. Para se obter o valor do PIB a preços de mercado (PIBpm), o único ajustamento necessário é somar impostos, líquidos 
de subsídios, que incidem sobre os bens e serviços entre o fim da produção e a venda, isto é, os impostos sobre o consumo:

\section{$\mathrm{PIB}=\Sigma \mathrm{VABi}+($ Impostos - Subsídios)sobre o consumo}

(sendo i cada uma das empresas da economia).

\subsection{3 Ótica do rendimento}

Nessa ótica, o valor do PIB é calculado a partir dos rendimentos de fatores produtivos distribuídos pelas empresas. O PIB corresponde à soma dos rendimentos do fator trabalho com os rendimentos dos outros fatores produtivos, que nas contas nacionais brasileiras aparecem agrupados numa única rubrica designada Excedente Operacional Bruto (EOB). São também incluídos os rendimentos distribuídos ao Estado sob a forma de impostos. Assim, na ótica do rendimento:

\section{PIB = Remunerações do trabalho + + Excedente Operacional Bruto + Impostos}

Os indicadores econômicos agregados (produto, renda, despesa) indicam os mesmos valores para a economia como um todo. Dividindo-se esse valor pela população de um país, obtém-se um valor médio por habitante (ou per capita). Assim, o PIB (isto é, a renda) per capita de um país num dado período nada mais é do que a razão entre o PIB e sua população.

A variável taxa de desemprego informa o percentual de trabalhadores sem ocupação no mercado de trabalho. O que se denomina força de trabalho diz respeito aos trabalhadores que efetivamente estão à procura de empregos; assim, indivíduos aposentados, estudantes e aqueles que por algum motivo não procuram trabalho não estão incluídos.

Considerando as dimensões quantitativa e qualitativa dessa variável, importa observar que não basta que o nível de emprego cresça; numa estratégia de desenvolvimento, é crucial que se elevem a oferta e a demanda de postos de trabalho de maior qualificação, e que se reduzam a rotatividade no mercado de trabalho e a distância entre os maiores e menores salários. Tais fatores, ademais, devem ser associados a políticas de aumento da produtividade do trabalho e do capital, que possibilita a elevação do rendimento médio dos trabalhadores (definido pela razão entre o total de salários efetivamente pagos e a população economicamente ativa, isto é, a força de trabalho), concomitantemente à redução das disparidades (variância) dos rendimentos do trabalho. 
Essa questão,porsua vez, nos leva a uma variável-chave do desenvolvimento, a distribuição da renda na sociedade. A distribuição mais homogênea e equânime da renda é uma condição necessária, mas não suficiente, para que uma nação possa ser qualificada como desenvolvida. Isso vale tanto para a dimensão individual da apropriação da renda (distribuição pessoal), quanto para a distribuição funcional, que avalia como a renda se distribui entre os fatores de produção (trabalho e capital).

Algumas observações devem ser feitas desde já. A primeira delas referese ao crescimento do Produto Interno Bruto. Nos últimos dez anos, a taxa média de crescimento desse indicador foi de 3,6 \%, o que pode ser considerado uma taxa elevada. A simples manutenção dessa taxa, no quadro de turbulência internacional que prevalece atualmente, já pode ser considerada uma projeção otimista.

Outra observação, indispensável para o exame do comportamento da renda per capita, diz respeito aos indicadores demográficos. A taxa de crescimento populacional do país tem caído nos últimos anos e todos os estudos mostram que esse processo continuará nas próximas décadas. Assumimos, assim, em consonância com o que está sendo adotado no conjunto do presente estudo, a estimativa feita pelo IBGE que aponta para uma população de 216.410.030 habitantes em 2030. A população brasileira em 2010 era de 190.755.799, o que significa que a taxa de crescimento demográfico, nesse horizonte de vinte anos, terá sido de 0,63\% a.a.

Deve-se, no entanto, ponderar que a trajetória provável de crescimento populacional - que mostra uma tendência ao envelhecimento - não eliminará o crescimento da parcela que compõe a PEA. Essa observação tem importância para o exame do desempenho do rendimento médio do pessoal ocupado.

Para o salário mínimo, adotou-se a hipótese de permanência do acordo em vigor pelo qual o SM aumenta, a cada ano, em um percentual correspondente a variação do PIB, acrescido da inflação. Como se trabalha aqui com preços constantes de 2010, a variação do salário mínimo acompanhará o crescimento do PIB ${ }^{13}$.

Para os indicadores de distribuição de renda, seguiu-se aquilo que as boas práticas sugerem: o coeficiente de Gini, para a distribuição pessoal, e a participação dos rendimentos do trabalho no PIB, para a distribuição funcional. Cabe, no entanto observar, que, como se faz usualmente, o coeficiente de Gini aqui utilizado toma por base os dados da PNAD (Pesquisa Nacional por Amostra de Domicílios). Nessa pesquisa, mais de $96 \%$ das rendas declaradas correspondem a rendas do trabalho e

13 Essa regra, decorrente de acordo firmado entre o Governo e os sindicatos, foi adotada pela Lei $\mathrm{N} \circ 2.382$, de 25/02/2011, que fixou, em seu art. $2^{\circ}$, as diretrizes para a política de valorização do salário mínimo a vigorar entre 2012 e 2015. O segundo parágrafo daquele artigo estabelece que "os reajustes para a preservação do poder aquisitivo do salário mínimo corresponderão à variação do INPC, calculado e divulgado pelo IBGE, acumulada nos doze meses anteriores ao mês do reajuste". Já o parágrafo quarto determina que, a título de aumento real, será aplicado o percentual correspondente à taxa de crescimento real do PIB. 
a transferências públicas - o que acarreta uma limitação: os valores assim obtidos não permitem uma visão mais ampla da distribuição de renda, que leve em conta a desigualdade entre rendimentos do trabalho e do capital.

As variáveis relacionadas ao desempenho das contas públicas, taxa de juros, taxa de câmbio e balanço de pagamentos são, junto com os indicadores de variação do nível de preços, as que sempre ocupam a centro das atenções dos estrategistas e planejadores. Cabem aqui, por isso mesmo, algumas reflexões sobre as políticas que afetam essas variáveis ${ }^{14}$ :

- A gestão da política monetária tem sido pautada pelo controle daspressõesinflacionárias quaseexclusivamente via contenção da demanda agregada, utilizando a taxa básica de juros (Selic) como principal instrumento. Assim, independentemente das origens ou das causas das pressões inflacionárias (que podem advir, por exemplo, de aumentos temporários de custos derivados de elevações das cotações internacionais de commodities, como ocorreu no início de 2008) ${ }^{15}$, a resposta tem sido a mesma: aumento dos juros básicos. Isso tem gerado elevada taxa de sacrifício para a sociedade brasileira, na medida em que têm sido necessárias doses elevadas de taxas de juros para se obter modestas reduções da inflação. Essa taxa de sacrifício manifesta-se no crescimento da economia abaixo da sua capacidade e na quase persistente apreciação da taxa de câmbio, com efeitos deletérios tanto sobre o setor privado (perda de competitividade do produtor doméstico) quanto sobre o setor público (custos fiscais associados às despesas líquidas de juros).

- Em relação ao câmbio, há quase um consenso em relação ao patamar problemático em que se encontra, tanto pelas consequências indesejáveis para o comércio exterior, quanto para a configuração da estrutura produtiva. Grosso modo, o nível de sobrevalorização da taxa de câmbio impacta negativamente sobre a competitividade das exportações brasileiras, sobretudo as manufaturadas de maior valor agregado. Com isso, consolida-se uma tendência à "primarização" da pauta de exportações que compromete o

14 Os autores advertem, desde já que, em sua opinião, a taxa de inflação não é uma variável relevante para o desempenho econômico em longo prazo. Adorou-se por isso a hipótese de que permanecerá no centro da meta, ao longo do período.

15 Ver Werneck Vianna, Modenesi e Bruno (2008). 
desempenho da economia brasileira, agravando sua restrição externa. As formas de correção desse desequilíbrio ainda estão em aberto. A imposição de controles, em particular sobre a entrada de capitais, constitui uma possibilidade; mas a necessidade de um marco regulatório mais adequado para o mercado futuro de câmbio e derivativos deve compor a agenda de discussão sobre o tema.

- No caso da política fiscal, há diversas razões para contestar o senso comum sobre o "inchaço" das despesas governamentais e o descontrole do gasto público. Sem dúvida, há evidências suficientes para corroborar a visão de que a estrutura tributária é pouco funcional, prejudicando o setor produtivo e contribuindo para uma concentração maior da renda. Uma alternativa que se apresenta viável, ainda que precise ser aprofundada e validada por pesquisas futuras, consiste em um redirecionamento da política fiscal, que possa contemplar a ampliação das despesas públicas de investimento e a queda da carga tributária nos setores produtivos. Nesta perspectiva, o avanço dos investimentos públicos poderia vir a constituir o cerne de uma política macroeconômica para o desenvolvimento, sobretudo porque são autofinanciáveis, já que elevam o estoque de riqueza real e as capacidades produtiva e contributiva da sociedade. É importante destacar os efeitos positivos que uma inflexão dessa natureza na política fiscal teria sobre as expectativas empresariais: os investimentos público e privado são complementares, e não substitutos, como postula a teoria convencional.

Tais constatações reforçam a importância e fundamentam a necessidade de uma articulação entre as políticas macroeconômicas, vinculando-as, também, ao objetivo do desenvolvimento, entendido na sua forma multidimensional e complexa: politicamente soberano, socialmente inclusivo e ambientalmente sustentável. Para tanto, é preciso identificar a estrutura institucional que condiciona esse processo, assim como promover uma convergência em torno de uma convenção de desenvolvimento discutida e articulada pelos diferentes atores sociais.

Essa articulação da política econômica faz-se ainda mais necessária ao se considerar a transição demográfica por que o país está atravessando, que durará até as próximas décadas. Entre outros efeitos, a mudança na estrutura etária da população está elevando rapidamente a participação da PIA (População em Idade Ativa) — que é uma proxy da oferta potencial de força de trabalho - na população total do país. A consequência dessa tendência será fazer com que o potencial produtivo tenda a crescer 
ao mesmo tempo em que a razão de dependência econômica (número de crianças e idosos por família) está a cair. Se a transição demográfica constituirá uma "janela de oportunidade" - ou se será (mais) uma oportunidade desperdiçada — dependerá da estratégia de desenvolvimento escolhida pela sociedade e de sua política econômica subjacente. Em outros termos, a economia brasileira tem de fazer a sua parte a fim de que o bônus demográfico não se converta em ônus demográfico, pela escassez de oportunidades de trabalho para o conjunto da sociedade.

O Brasil ainda possui uma condição privilegiada para executar sua política de desenvolvimento, pois conta com um conjunto de bancos públicos capazes de estimular o investimento privado e financiar o investimento público em setores estratégicos. As limitações do sistema financeiro, por seu turno, demandam uma reforma com vistas a torná-lo funcional às necessidades da economia brasileira e, assim, apoiar as mudanças estruturais intrínsecas ao processo de desenvolvimento.

O quadro apresentado adiante permite visualizar o comportamento das variáveis macroeconômicas relevantes nos três cenários diferentes, tendo como ponto de partida o desempenho dessas mesmas variáveis no ano de 2010.

\section{3 | Observações Indispensáveis sobre Investimento, Balanço de Pagamentos e Inserção Externa}

\subsection{1 | As dimensões comercial e financeira da inserção externa}

O conceito de inserção externa envolve duas dimensões essenciais, a comercial e a financeira. A análise de sua evolução requer a consideração de aspectos macroeconômicos (como o regime cambial adotado, que define o método de fixação da taxa de câmbio e sua dinâmica de ajustamento) e estruturais (essencialmente, os graus de abertura comercial e financeira das economias e a estrutura de comércio exterior e do sistema financeiro).

A interação entre os dois conjuntos de fatores moldará as características dos fluxos financeiros e comerciais entre o país e o exterior. Todavia, o volume e a composição efetiva desses fluxos dependem também de fatores externos aos países, especificamente, da dinâmica da economia internacional em cada momento da história. A influência desta dinâmica revela-se mais intensa no caso dos países periféricos, como o Brasil.

No contexto atual de globalização financeira, a relação entre o regime cambial e o comportamento dos fluxos comerciais e financeiros tornou-se ainda mais complexa. Nos países que adotaram um grau elevado de abertura financeira, a dinâmica dos fluxos de capitais sobrepõe-se, em geral, àquela dos fluxos comerciais, exercendo 
influência decisiva sobre a trajetória dos balanços de pagamentos e o comportamento da taxa de câmbio. Neste contexto, a escolha do regime cambial constitui uma decisão estratégica (e não trivial) de política econômica. Os regimes de câmbio administrado (fixo ou bandas cambiais), que prevaleceram nos países periféricos até meados da década de 1990, têm o mérito de garantir a estabilidade da taxa de câmbio nominal, um dos preços-chave das economias capitalistas, mas se revelaram extremamente suscetíveis à apreciação da taxa de câmbio real e a ataques especulativos, que culminaram em sucessivas crises cambiais na segunda metade daquela década, dentre as quais a crise brasileira de 1998-1999. Após essas crises, as políticas de câmbio fixo ou semifixo (tipo crawling peg) cederam lugar aos regimes de flutuação suja na maioria desses países, incluindo o Brasil. Todavia, num contexto de alta mobilidade de capitais, esses regimes podem resultar em volatilidade excessiva da taxa de câmbio, com implicações negativas sobre as decisões de investimento e de exportação. Essa volatilidade, por sua vez, dependerá tanto do grau de abertura financeira da economia como da forma de interação entre a autoridade monetária e os agentes privados no mercado de câmbio.

É importante questionar se a melhora dos indicadores tradicionais de solvência eliquidezsignifica uma redução efetiva da vulnerabilida de externa da economia brasileira. Algumas dimensões da inserção externa do país no período analisado não são captadas por esses indicadores (como as aplicações dos investidores estrangeiros no mercado doméstico de derivativos financeiros) ou ainda não transpareceram (como o aumento do estoque de títulos públicos detido por investidores estrangeiros após o incentivo tributário concedido em fevereiro).

Pode-se levantar a hipótese de que uma nova dimensão da vulnerabilidade externa esteja emergindo em função do peso cada vez mais relevante dos investidores estrangeiros nos diversos segmentos do mercado financeiro doméstico (ações, títulos públicos, derivativos), viabilizado pelo aprofundamento da abertura financeira após o ano 2000, que reforçou as correias de transmissão da instabilidade gerada nos mercados financeiros internacionais para as economias periféricas. Ademais, a unificação dos mercados de câmbio em março de 2005 significou a flexibilização das saídas de capitais pelos residentes e, assim, ampliou potencialmente a mobilidade da riqueza financeira aplicada em títulos de dívida pública de curto prazo.

Em relação à solvência externa, o indicador mais amplo (passivo externo líquido/exportações) estabilizou-se desde 2004 no patamar de 4,0 e possivelmente não ultrapassará esse piso nos próximos anos. A perda de rentabilidade das exportações foi praticamente generalizada em 2005 e o conjunto de fatores que contribuíram para o desempenho favorável das vendas externas num contexto de apreciação cambial deve perder fôlego em 2006 e 2007. Ademais, a estrutura da nossa pauta exportadora, concentrada em commodities primárias, é especialmente vulnerável a mudanças na dinâmica do comércio internacional (PRATES, 2006). 
Se, por um lado, as duas dimensões do cenário externo benigno expansão da economia e do comércio mundiais e ampla liquidez internacional - se autorreforçaram na fase de "euforia" do ciclo, por outro lado, essa mesma relação simbiótica pode-se manifestar na fase descendente. Uma redução do crescimento nos países centrais induzida, por exemplo, pela alta da taxa de juros básica nos Estados Unidos e/ou pelo impacto recessivo dos elevados preços do petróleo, comprometerá o desempenho comercial dos países emergentes, o que pode deteriorar seus respectivos fundamentos e, consequentemente, as expectativas dos investidores. Nesse contexto, não é implausível conjecturar as possibilidades de piora tanto das condições de liquidez quanto de solvência externa da economia brasileira.

\subsection{2 | O balanço de pagamentos: conta corrente e conta de capital}

A contabilização das relações econômicas de um país com o resto do mundo, do ponto de vista dos fluxos, respeita uma primeira grande divisão: as entradas e saídas de divisas que têm como contrapartida as saídas e entradas de bens e serviços, de um lado; e o movimento dos fluxos de capital, que geram compromissos financeiros a serem honrados no futuro, de outro.

O primeiro destes lados - a conta corrente do balanço de pagamentos - registra, portanto, o resultado da operação do assim chamado lado real da economia (bens e serviços não fatores) em suas conexões externas, acrescido das rendas (juros, lucros) decorrentes dos estoques de compromissos financeiros acumulados e das transferências unilaterais.

A economia brasileira, depois de um raro intervalo de superávits correntes, voltou a apresentar déficits nesse somatório de transações com o exterior. Pelo critério dos dados acumulados em 12 meses e como proporção do produto, desde o primeiro mês de 2008 o resultado é negativo, e evolui até os 2,4\% do produto interno bruto (PIB) do último dado disponível (setembro de 2010).

De maneira bastante resumida, podem ser apontados três grandes determinantes para esse movimento recente. Em primeiro lugar, o elevado ritmo de crescimento do Brasil, em uma conjuntura de fraco dinamismo da economia global (particularmente nos países desenvolvidos), que naturalmente se traduz em elevação das importações de bens e serviços e redução dos excedentes exportáveis. Neste contexto, os bons resultados operacionais das filiais de multinacionais aqui instaladas, em contraste com as dificuldades enfrentadas por boa parte das suas matrizes, também incentivam a elevação das remessas de lucros (BIANCARELI, 2011).

Em segundo lugar, a perda de dinamismo do comércio internacional outra face do cenário pós-crise - não apenas enfraquece as vendas externas do país, mas também incentiva um acirramento da disputa por mercados, notadamente por parte 
da China, com sua conhecida agressividade comercial. Isto ocorre apesar da recente diversificação de destinos das exportações brasileiras - com ganho de participação em mercados que se mantêm mais dinâmicos - e da manutenção em patamares elevados dos preços das commodities, cada vez mais essenciais para o saldo comercial. Por último, mas não menos relevante (muito ao contrário), o terceiro determinante é a acentuada trajetória de apreciação da taxa de câmbio em termos nominais e reais, que enfraquece a competitividade e vem alterando a estrutura produtiva e a pauta exportadora do país.

Mais importante que a descrição do comportamento recente, no entanto, é a trajetória futura da conta corrente. Estimativas disponíveis apontam, em graus variados, para uma ampliação moderada dos déficits. Para o Banco Central do Brasil (BCB), o resultado deve ficar negativo em-2,5\% do PIB, no ano de 2010, e igualmente negativo em 2,8\%, no ano de 2011.

Para o Fundo Monetário Internacional (FMI), que alonga seu cenário, a trajetória tende a ser mais acentuada: -2,6\% em 2010; -3,0\% em 2011; e flutuações ao redor de -3,3\% entre 2012 e 2015. As projeções de instituições financeiras domésticas são feitas em valores absolutos, e indicam evolução mais favorável: pela mediana, déficits de US\$ 50 bilhões em 2010; US\$ 64 bilhões em 2011; e estabilidade em torno de US\$ 61 bilhões de 2012 a 2014.

Independentemente das técnicas utilizadas ou da real capacidade de antecipação das tendências, principalmente para prazos mais dilatados, o relevante é atentar para as hipóteses que tornam estes cenários factíveis; e elas dizem respeito aos três grandes determinantes mencionados. Do ponto de vista do desempenho econômico brasileiro e mundial, o diferencial, ainda que não tão acentuado quanto em 2010, tende a permanecer por todo o horizonte visível.

Mais sombrias são as perspectivas para o comércio global e a sua capacidade de estimular as exportações brasileiras, a despeito de o futuro para a produção e as vendas de commodities seguir promissor em termos de preços e quantidades. No que se refere ao comportamento da taxa de câmbio, parece reduzido o espaço, e limitado o potencial, para maxidesvalorizações que pudessem reverter, por si, os déficits em conta corrente.

A esses devem ser acrescidos outros fenômenos que certamente terão impacto sobre a realidade das transações correntes, ainda que alguns em prazo mais longo. Em primeiro lugar, as perspectivas positivas para a economia não dizem respeito apenas à continuidade de taxas razoáveis de crescimento, mas também ao aprofundamento de um bloco concentrado no tempo de investimentos: nos setores ligados ao agronegócio, à energia, à construção civil e à infraestrutura urbana e de transportes (também com vistas à Copa do Mundo de 2014 e às Olimpíadas de 2016). Sem falar na viabilização dos projetos para a extração e processamento do petróleo da 
camada pré-sal, que demandarão inversões num patamar extraordinário - o plano de negócios da Petrobras cita o valor de US\$ 224 bilhões de investimento, somente desta empresa, até 2014. Tudo isto exigirá pesadas importações de bens de capital, que se somarão ao alto coeficiente importado já presente na estrutura de consumo das famílias brasileiras, e na própria estrutura de produção do país.

A tendência é, assim, de manutenção ou ampliação do déficit. Porém, pensando-se em um prazo mais longo e mais incerto, há indicações na direção contrária. A começar pela maturação dos investimentos industriais, de infraestrutura e do agronegócio, que por caminhos diferentes tendem a gerar aumento da competitividade e do potencial exportador do país. Mas principalmente por conta da extração e processamento do petróleo do pré-sal.

A quantidade e a qualidade do óleo encontrado e a importância estratégica deste produto (que não desaparecerá tão cedo) certamente fazem deste o grande trunfo externo da economia brasileira para as próximas gerações. Ainda há muitas dúvidas: a verdadeira extensão das reservas, os desafios tecnológicos e o tempo necessário para superá-los, e o preço do barril ao longo do período de exploração. Por isso, exercícios de projeção dos seus impactos sobre a conta corrente devem ser tomados com bastante cautela. Mas não é exagero considerar que, quando esta riqueza estiver sendo efetivamente explorada, as exportações líquidas de petróleo e seus derivados representarão uma fonte considerável e segura de geração de divisas - inclusive pelo fundo que manterá parte das receitas em dólar no exterior e internalizará seus rendimentos. Por mais que haja incertezas, este e os outros fatores citados não podem ser menosprezados (e muito menos desconsiderados) em qualquer análise sobre as perspectivas do setor externo da economia brasileira.

Em suma, se o cenário atual e as projeções para os próximos anos trazem números e processos que justificam a preocupação com as transações correntes, o futuro mais distante - e, obviamente, muito mais incerto - também autoriza, ainda que com muita cautela, expectativas de melhora.

\subsubsection{Enfim, o investimento}

Em que pese o fato de o investimento agregado no Brasil vir registrando, desde 2004, taxas de crescimento bem superiores às do PIB (à exceção de 2009), ainda assim o nível atual do investimento permanece em patamares considerados baixos (19,5\% do PIB em 2010 e 19,3\% do PIB em 2011), tanto em relação à média dos países em desenvolvimento, quanto em relação à média histórica do país. Ademais, no que concerne às possibilidades de o país ingressar num ciclo longo de crescimento sustentado, isto é, sem gerar pressões inflacionárias nem sobre o balanço de pagamentos. Há um relativo consenso, baseado na evidência empírica brasileira, de que o crescimento continuado 
a taxas próximas de 5\% ao ano requer uma taxa de investimento (formação bruta de capital em relação ao PIB) em torno de $25 \%$ do PIB.

A questão de fundo em relação ao investimento no Brasil remete, em última análise, ao padrão de crescimento que o país vem apresentando nos últimos anos. Assim, a expansão recente do investimento está majoritariamente associada aos setores que mais têm contribuído para o crescimento da economia: agronegócio e extrativismo mineral. Com efeito, os investimentos nos setores intensivos em recursos naturais e em escala respondem por cerca de $80 \%$ do total da formação bruta de capital.

O investimento é a variável-chave de uma economia; inserido numa estratégia adequada, funciona como ponte intertemporal entre diferentes estágios de desenvolvimento, permitindo a superação de gargalos de oferta e a implementação de transformações estruturais.

Neste sentido, o grande desafio para o desenvolvimento brasileiro é a expansão significativa do investimento em três setores estratégicos: infraestrutura urbana e logística, energia eindústria de transformação. É absolutamenteimprescindível a liderança do Estado nesse processo, em particular nos dois primeiros setores. Isso só será possível se forem retiradas, ou ao menos minimizadas, as amarras que o regime macroeconômico ainda impõe ao desenvolvimento no Brasil.

\section{4 | Cenário Otimista e Possível}

- O PIB crescerá a uma taxa de 4\% a.a. - taxa superior a verificada nos últimos dez anos, que foi de 3,6\%. Isso implica um crescimento vigoroso do nível de atividades econômicas e, portanto, um enfrentamento virtuoso dos obstáculos e restrições decorrentes da crise internacional, bem como a introdução de correções na implementação dos instrumentos de política econômica ${ }^{16}$.

- O PIB alcançará em 2030 o expressivo valor de R $\$ 8.260$ bilhões, a preços constantes de 2010.

- A renda per capita chegará a R \$38.240,00, a preços constantes de 2010, com uma população pouco superior a 216 milhões de habitantes. Esse valor corresponde (a preços constantes de 2010, em dólares e em reais) a cerca de 22 mil dólares anuais e

16 Vale observar que na seção sobre a política econômica e o debate atual, mencionamos que 4\% a.a., que foi o patamar médio alcançado no período 2004-2009, poderia ser considerado baixo. Pesa, na proposição ora apresentada, o impacto da situação internacional que, em nenhum caso, será totalmente favorável. 
poderá significar para a população brasileira a possibilidade de desfrutar de níveis de vida significativamente superiores aos de hoje. A condição para que isso ocorra é que a distribuição de renda também melhore, tanto no conceito de distribuição pessoal quanto no de distribuição funcional.

- O coeficiente de Gini, utilizado normalmente para a distribuição pessoal da renda deverá chegar a 0.40. Com isso ele estará situado em patamar mais favorável do que países da América Latina como Argentina (0.522), Venezuela $(49,1)$ e Uruguai $(0.446)$ e próximo aos observados em países de maior desenvolvimento como França (0.327), Inglaterra (0.36) e Estados Unidos (0.408).

- A participação dos rendimentos do trabalho no PIB - que serve como proxy para a distribuição funcional da renda - poderá chegar a $50 \%$, o que significa um crescimento expressivo, mas possível.

- A hipótese adotada para a projeção do salário mínimo - que é a da continuidade do acordo firmado com os sindicados levará o salário mínimo ao valor de R\$ 1.118,00em 2030.

- O rendimento médio do pessoal ocupado apresentará em 2030 um desempenho positivo, apresentando um crescimento superior ao da renda per capita.

- Níveis de emprego e taxas de desemprego apresentarão resultados favoráveis em 2030, com aumento substancial do primeiro - principalmente no segmento de trabalhadores com carteira assinada - e redução significativa do segundo indicador.

- A taxa básica de juros convergirá para a taxa média praticada nos países da OCDE $(1,65 \%)^{17}$, o que indica ter havido uma alteração radical nas condições fiscais e financeiras do Estado brasileiro: o serviço da dívida pública terá experimentado uma redução significativa e as contas públicas apresentarão um resultado primário próximo de zero.

- O Estado, em consequência, terá readquirido sua capacidade de endividamento e de utilização d o gasto como instrumento de promoção do crescimento e do emprego. 
- A taxa de câmbio terá sofrido pronunciada desvalorização, condizente com as políticas macroeconômicas centradas no crescimento econômico e na promoção do emprego; seu valor oscilará em torno de $\mathrm{R}$ \$2,50 por dólar.

- O comportamento do balanço comercial é de difícil previsão, não apenas em virtude da instabilidade do comércio mundial em tempos de crise, mas principalmente porque, se o desenvolvimento experimentado pelo país fará crescer as exportações (principalmente de manufaturados e serviços de maior valor agregado), fará crescer também as importações, principalmente de bens de capital e bens intermediários, indispensáveis à sustentação do crescimento.

- O resultado da conta corrente do balanço de pagamentos apontará para uma situação de maior conforto para a gestão das políticas macroeconômicas.

- A inflação, controlada não apenas pelos instrumentos convencionais de política monetária, mas por políticas adequadas à consolidação das tendências de crescimento da economia, ocupará o centro da meta.

\subsection{Cenário Pessimista e Plausível}

- O PIB crescerá a uma taxa de 0,63\%, que é exatamente a taxa de crescimento populacional. Isso significa que as vicissitudes do quadro internacional não serão adequadamente enfrentadas e que recrudescerá o viés conservador e monetarista da política econômica.

- O valor do PIB, no horizonte considerado será de R\$4.277 bilhões, a preços de 2010.

- A renda per capita permanecerá a mesma de 2010: $\mathrm{R}$ \$19.763,50, o que significa um empobrecimento relativo da população brasileira e acarreta impactos negativos na distribuição de renda.

- A tendência à melhoria da distribuição pessoal da renda, medida pelo coeficiente de Gini, será, portanto, detida e esse indicador estabilizará no patamar de 0,60.

- Igual tendência experimentará a distribuição funcional da renda, medida pela participação dos rendimentos do trabalho 
no PIB, que, se não cair, deverá na melhor hipótese permanecer no mesmo nível de 2010.

- O salário mínimo, nos marcos da hipótese anteriormente mencionada, relativa à continuidade do acordo com os sindicatos, não ultrapassará $\mathrm{R} \$ 578,00$, o que pode ser um fator a alimentar tensões sociais e disputas trabalhistas.

- O rendimento médio do pessoal ocupado tenderá a crescer a uma taxa inferior à da renda por habitante, tanto em função do baixo valor do salário mínimo, que baliza e serve como piso salarial no mercado de trabalho, quanto pelas pressões oriundas da transição demográfica que se encontrará em fase avançada; em 2030, no cenário mais provável (o que os demógrafos denominam variante média populacional), a estrutura etária da população brasileira estará fortemente concentrada nas faixas adultas (grupos etários entre 15-19 e 50-54 anos); com o baixo crescimento, não será possível evitar as implicações da dinâmica demográfica em termos de perda de poder de barganha dos trabalhadores nas negociações salariais e de aumento do grau de informalização e da precarização no mercado de trabalho.

- Nível de emprego e taxa de desemprego refletirão as condições negativas do desempenho da economia brasileira, reduzindo-se o primeiro e elevando-se a segunda; a ausência de crescimento do emprego está relacionado com as tendências negativas dos indicadores de distribuição de renda e do rendimento médio do pessoal ocupado.

- A taxa básica de juros permanecerá nos níveis atuais (10\% a.a.), em decorrência da continuidade de políticas conservadoras que priorizam o controle inflacionário e a atração de capitais externos para o fechamento do balanço de pagamentos.

- As contas públicas continuarão a sofrer progressiva deterioração, em virtude tanto do baixo crescimento quanto da permanência das taxas de juros em patamares elevados; superávits primários crescentes continuarão a ser a meta da política econômica para permitir o pagamento das despesas financeiras relacionadas ao serviço da dívida pública.

- A taxa de câmbio permanecerá sobrevalorizada, mantendo-se em níveis semelhantes aos de hoje (R\$ 1,80 por dólar). 
- As contas externas (balanço comercial e balanço das transações correntes) não sofrerão grande alteração.

- A inflação ocupará o centro da meta.

\subsection{Cenário Conservador e Provável}

- O PIB crescerá a uma taxa inferior á da média dos últimos dez anos - 2,0\% a.a. - mas superior á taxa de crescimento demográfico. O impacto da crise internacional sobre a economia brasileira será assim significativo e a adoção de instrumentos de política econômica voltados para o crescimento e a promoção do emprego será tímida.

- O PIB registrará, em 2030, o montante de R\$ 5.602 bilhões.

- A renda per capita crescerá, mantendo a tendência dos últimos anos, e alcançará o valor de $\mathrm{R}$ \$25.935,00.

- A distribuição de renda, em ambos os conceitos, continuará a melhorar: o coeficiente de Gini, tal qual no cenário anterior, estabilizará 0.60 e a participação dos rendimentos do trabalho no PIB experimentará moderada melhoria.

- O salário mínimo vigente em 2030 será de $\mathrm{R}$ \$758,00, respeitada a hipótese adotada nos demais cenários.

- Orendimento médio do pessoal ocupado tenderá a acompanhar, em maior ou menor grau, a evolução da renda por habitante; ainda que menos intensos do que no cenário pessimista, os efeitos da transição demográfica também se farão sentir, e o mercado de trabalho dificilmente será capaz de absorver a população em idade laboral (e particularmente as camadas mais jovens) que constituirá a larga maioria da população total; as pressões daí advindas imp'licarão também em aumento da informalidade e da precarização nas relações de trabalho.

- Nível de emprego e taxa de desemprego permanecerão nos mesmos patamares em que se encontram na atualidade.

- A taxa básica de juros convergirá para a média das que são praticadas pelos países emergentes ${ }^{18}$, chegando a 4,35\% a.a.;

18 Fonte: OCDE (Dataset MEI) e FMI (IFS Novembro 2011). Foram considerados, para cálculo da média, os seguintes países: Argentina, Chile, China, Colômbia, República Tcheca, Egito, Hungria, Índia, Indonésia, Israel, Jordânia, 
esse nível é consistente com as projeções de crescimento moderado da economia.

- A taxa de câmbio oscilará em torno de R\$2,00 por dólar, o que significa uma leve desvalorização.

- As contas externas (balanço comercial e balanço das transações correntes) não sofrerão grande alteração. 


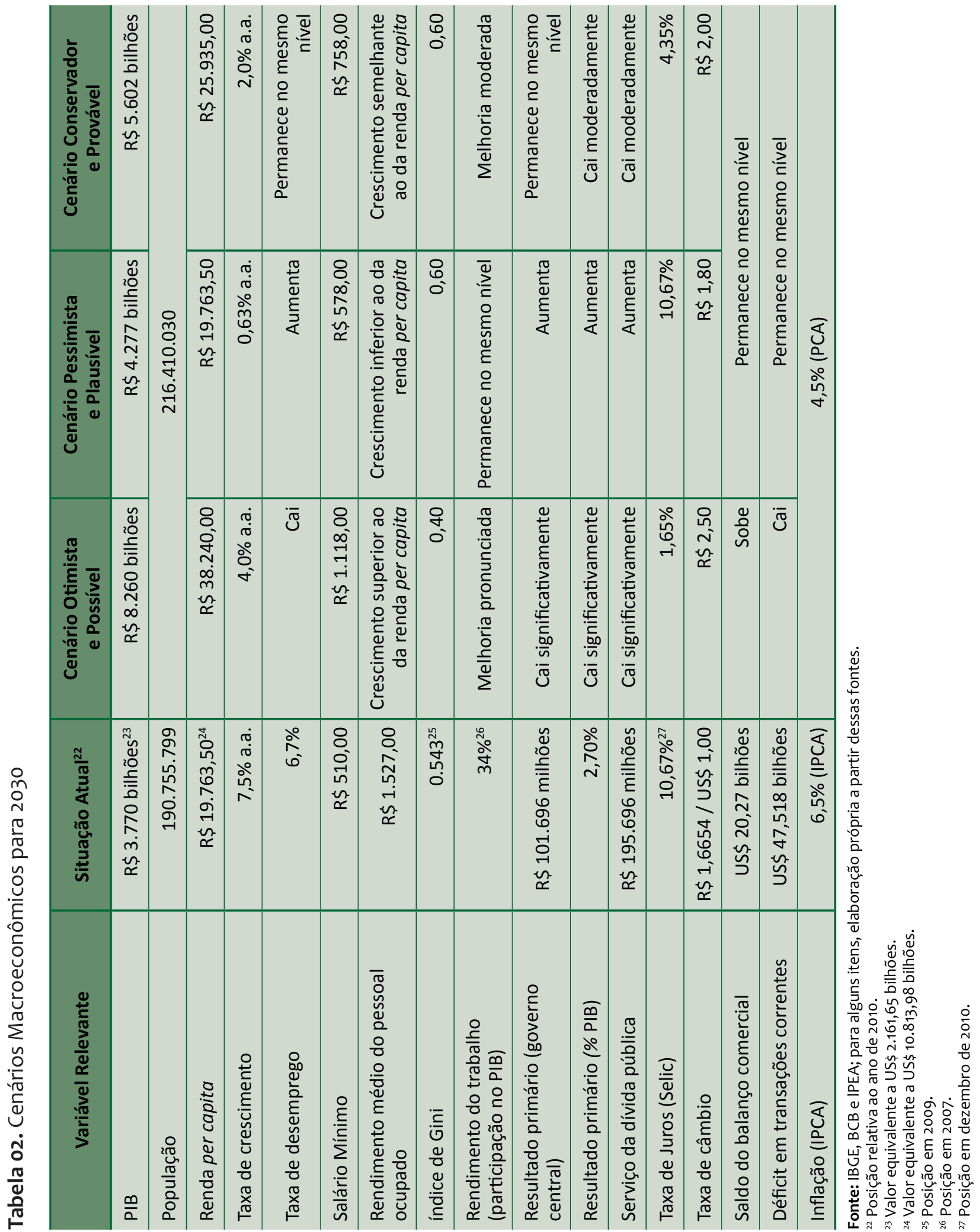




\section{6 | À GUISA DE CONCLUSÃO}

O presente texto procurou desenhar os cenários macroeconômicos possíveis, em um horizonte de vinte anos, com vistas a subsidiar um estudo mais amplo, voltado para o planejamento do sistema de saúde brasileiro a médio e longo prazo.

Levando em conta as limitações que os estudos prospectivos sempre apresentam, apresentaram-se desde logo as dificuldades de ordem analítica e metodológica que necessariamente se colocam para a construção de cenários.

Tais dificuldades são acrescidas, na atual fase de desenvolvimento do capitalismo brasileiro, pela ocorrência de uma crise internacional, extensa e profunda, cujos desdobramentos ainda não permitem ver o seu fim. Com isso, uma combinação de fatores externos e internos gera instabilidade, que resulta tanto da dinâmica contraditória do desenvolvimento capitalista quanto da incerteza com que os detentores da riqueza, dentro e fora do país (responsáveis, em última instância, pelas decisões de investimento) - incerteza essa que tolda o horizonte com tintas sombrias - olha para o futuro.

Por outro lado, e o estudo procurou explorar esse aspecto, o país dispõe de um conjunto de fatores que podem favorecer o enfrentamento da turbulência externa e encontrar caminhos para que o cenário virtuoso se confirme. Tais fatores envolvem elementos de ordem concreta - da transição demográfica à plataforma pré-sal - e de ordem institucional - em especial o sistema de bancos públicos de que o país dispõe. E envolvem também fatores de ordem subjetiva, manifestos na inflexão que a política macroeconômica parece estar experimentando.

Heródoto nos conta que Creso, rei da Lídia, consultou o Oráculo, antes de atacar a Pérsia, e recebeu da pitonisa a seguinte resposta:

\section{- Se você o fizer, destruirá um grande império.}

Certo de que se tratava do Império Persa, Creso lançou-se à guerra e foi completamente derrotado. O império que seria destruído era o seu.

O Oráculo nunca nos dá respostas claras e simples. Ao contrário. Assim, para desvendar o mistério do futuro, é preciso decodificar a linguagem simbólica com que se apresentam os sinais do tempo que se aproxima.

Se os decodificarmos corretamente - mesmo levando em conta que o cenário conservador é o mais provável — poderá o país tomar as decisões e escolher as políticas que levarão à realização do cenário otimista.

Se não o conseguirmos, estará à espreita o cenário pessimista. 


\section{7 | REFERÊNCIAS BIBLIOGRÁFICAS}

BIANCARELI, A. M. Riscos na travessia? O financiamento externo e os desafios futuros da economia brasileira. In: CARNEIRO, R. M. \& MATIJASCIC, M. Desafios para o desenvolvimento brasileiro. Brasília: IPEA, p. 87-102, 2011.

BRASIL. MINISTÉRIO DE CIÊNCIA E TECNOLOGIA. CNPq: cenários socioeconômicos e científicotecnológicos para o Brasil. Brasília, 1989. Mimeo.

BRASIL. MINISTÉRIO DO PLANEJAMENTO, ORÇAMENTO E GESTÃO. SECRETARIA DE PLANEJAMENTO E INVESTIMENTOS ESTRATÉGICOS. Plano Plurianual 2012-2015 (PPA): projeto de lei. Brasília: MPOG; Secretaria de Planejamento e Investimentos Estratégicos, 2011. 278 p.

BRASIL. SECRETARIA DE ASSUNTOS ESTRATÉGICOS (SAE). Cenários exploratórios do Brasil 2020: texto para discussão. Brasília: SAE, 1997.

BRASIL. PRESIDÊNCIA DA REPÚBLICA. SECRETARIA DE ASSUNTOS ESTRATÉGICOS (SAE). Brasil 2022. Brasília: Presidência da República, SAE, 2010. 100 p. il.

BUARQUE, S. Metodologia e técnicas de construção de cenários globais e regionais. Brasília: Ipea, 2003. 71 p. Texto para discussão n. 939.

CARDOSO JÚNIOR, J.C. (Org.) Brasil em desenvolvimento 2010: Estado, planejamento e políticas públicas. Brasília: IPEA, 2010.

GLOBAL BUSINESS NETWORK (GBN). GBN Scenarios Book: Search for Vision 2000. Emeryville, CA: GBN, 1991.

GLOBAL BUSINESS NETWORK (GBN). The logics of change: 1995 GBN Scenario Book. Emeryville, CA: GBN, 1995.

GEUS, A. Prospectiva: por qué? cómo? — siete ideas claves. In: ORTEGON, E.; VASQUEZ, J. (org.). Prospectiva: construcción del futuro. Santiago de Cali: ILPES / Universidad del Valle, 1997, p. 180-197.

GIAMBIAGI, F. \& BARROS, O. Brasil pós-crise: agenda para a próxima década. Rio de Janeiro: Editora Campus / Elsevier, 2009.

GIAMBIAGI, F.; PORTO, C. (Org.). 2022: proposta para um Brasil melhor. No ano do bicentenário. Rio de Janeiro: Campus-Elsevier, 2011.

GODET, M. Manual de prospectiva estratégica: da antecipação à acção. Lisboa: Dom Quixote, 1993. 406 p. (Gestão \& Inovação)

INGELSTAM, L. La planificación del desarrollo a largo prazo: notas sobre su esencia y metodologia. Revista de la Cepal, Santiago del Chile, n. 31, p. 69-76, 1987.

INSTITUTO DE PESQUISA ECONÔMICA APLICADA (IPEA). O Brasil na virada do século: trajetória do crescimento e desafios do desenvolvimento. Brasília: Ipea, 1997.

JAGUARIBE, H. Brasil 2000: para um novo pacto social. São Paulo: Paz e Terra, 1986. 200 p.

JAGUARIBE, H. et al. Brasil: reforma ou caos. São Paulo: Paz e Terra, 1989. 308 p. 
JOUVENEL, H. Sobre la práctica prospectiva: uma breve guía metodológica. In: VÁSQUEZ, J. M.; ORTEGÓN, E. Prospectiva: construcción social Del futuro. Santiago de Cali: Ilpes; Univesidad Del Valle, 1997. p. 180-197.

KAHN, H e WIENER, A. J. O ano 2000: uma estrutura para especulação sobre os próximos trinta e três anos. São Paulo: Melhoramentos/USP, 1968.

MACROPLAN. PROSPECTIVA ESTRATÉGIA \& GESTÃO. Prospectiva e estratégia: construção de cenários e prospecção de futuros - material didático para treinamento. Rio de Janeiro, 1996. Mimeo.

MARCIAL, E. C.; GRUMBACH, R. J. S. Cenários prospectivos: como construir um futuro melhor. Rio de Janeiro: Editora FGV, 2002.

MATTEI, L. Gênese e agenda do novo desenvolvimentismo brasileiro. IV Encontro Internacional da Associação Keynesiana Brasileira (AKB), Rio de Janeiro, ago. 2011.

MCRAE, H. O mundo em 2020: poder, cultura e prosperidade, uma visão do futuro. São Paulo: Record, 1998.

MONTGOMERY, C.; PORTER, M. (Orgs.). Estratégia: a busca da vantagem competitiva. Rio de Janeiro: Campus, 1998. 528 p.

MORITZ, G. O.; PEREIRA, M. F. Planejamento de cenários: a evolução do pensamento prospectivo. Revista de Ciência da Administração, Santa Catarina, v. 7, n. 13, 2005.

ORTEGON, E.; VASQUEZ, J. E. M. (Org.). Prospectiva: construcción del futuro. Colombia: Ilpes; Universidad del Valle, 1997.

PINHEIRO, A. C.; GIAMBIAGI, F. Rompendo o marasmo: a retomada do desenvolvimento no Brasil. Rio de Janeiro: Campus-Elsevier, 2006. 344 p.

PORTER, M. Vantagem competitiva: criando e sustentando um desempenho superior. Rio de Janeiro: Campus, 1989.

PORTO, C. A.; SOUZA, N. M.; BUARQUE, S. C. Construção de cenários e prospecção de futuros. Recife: Litteris, 1991.

PORTO, C. A. Quatro cenários para o Brasil 2005-2007. Rio de Janeiro: Garamond, 2005.

PRATES, D. M.: A inserção externa da economia brasileira no governo Lula. In: CARNEIRO, R. M. (Org.) A supremacia dos mercados e a política econômica do Governo Lula. São Paulo: Ed. Unesp, p 133-171, 2006.

RATTNER, H. Estudos do futuro: introdução à antecipação tecnológica e social. Rio de Janeiro: Editora FGV, 1979.

RATTNER, H. Considerações sobre tendências da futurologia contemporânea. Revista de Administração de Empresas, São Paulo, v. 13, n. 3, p. 89-103, 1973.

SARDENBERG, R. M. A política brasileira para os cenários da globalização: conferência no curso de aperfeiçoamento em políticas públicas. Rio de Janeiro: Escola de Políticas Públicas e de Governo (UFRJ), 1996. p. 6-8.

SCHWARTZ, P. A arte da previsão. São Paulo: Scritta, 1995. 
SCHWARTZ, P. A arte da visão de longo prazo: planejando o futuro em um mundo de incertezas. São Paulo: Best Seller, 2000.

SCHWARTZ, P.; LEYDEN, P. The long boom: a history of the future 1980-2020. San Francisco: Wired Magazine, 1997.

SERRANO, F. e SUMMA, R. Política macroeconômica, crescimento e distribuição de renda na economia brasileira dos anos 2000. Observatório da Economia Global. Textos Avulsos no 6, março de 2011.

SIMONSEN, M. H. Brasil 2001. 5.ed. Rio de Janeiro: Apec Editora, 1975.

VAN DER HEIJDEN, K. Scenarios: the art of strategic conversation. Chichester, New York, Brisbane, Toronto, Singapura: John Wiley \& Sons, 1996.

VELLOSO, J. P. R. (Coord.). O desafio da China e da Índia: a resposta do Brasil. Rio de Janeiro: José Olympio, 2005.

WACK, P. Cenários: águas desconhecidas à frente. In: MONTGOMERY, C. A. Estratégia: a busca da vantagem competitiva. 2. ed. Rio de Janeiro: Campus, p. 363-394, 1998.

WERNECK VIANNA, S., MODENESI, A. M. e BRUNO, M. Reversão preventiva na política monetária (Nota técnica). Rio de Janeiro: IPEA, 2008.

WERNECK VIANNA, S. T.; BRUNO, M.; MODENESI. A. Macroeconomia para o desenvolvimento: uma agenda de pesquisa. IPEA, Texto para Discussão 1667. Rio de Janeiro, dezembro de 2011.

WERNECK VIANNA, S. et al. Macroeconomia para o Desenvolvimento: crescimento, estabilidade e emprego (Projeto Perspectivas para o Desenvolvimento Brasileiro). Brasília: IPEA, 2010.

WORLD BANK. Global economic prospects and the developing countries. Washington, 1997. 